\title{
A 5500-year oxygen isotope record of high arctic environmental change from southern Spitsbergen
}

\section{Arppe, Laura}

2017-12

Arppe , L , Kurki , E , Wooller , M J , Luoto , T P , Zajaczkowski , M \& Ojala , A E K 2017 , ' A 5500 -year oxygen isotope record of high arctic environmental change from southern

Spitsbergen ' , Holocene , vol. 27 , no. 12 , pp. 1948-1962 . https://doi.org/10.1177/0959683617715698

http://hdl.handle.net/10138/307946

https://doi.org/10.1177/0959683617715698

unspecified

acceptedVersion

Downloaded from Helda, University of Helsinki institutional repository.

This is an electronic reprint of the original article.

This reprint may differ from the original in pagination and typographic detail.

Please cite the original version. 
1 Author's Accepted manuscript

2 The Holocene, 27(12), 1948-1962.

$3 \quad$ https://doi.org/10.1177/0959683617715698

4

5 A 5500-year oxygen isotope record of high arctic

6 environmental change from southern Spitsbergen

7

8 Laura Arppe, ${ }^{1}$ Eija Kurki, ${ }^{2}$ Matthew J Wooller, ${ }^{3,4}$ Tomi P Luoto, ${ }^{5}$ Marek

9 Zajączkowski, ${ }^{6}$ Antti EK Ojala ${ }^{7}$

$11{ }^{1}$ Finnish Museum of Natural History, University of Helsinki, Finland

12 2Department of Geosciences and Geography, University of Helsinki, Finland

$13{ }^{3}$ Water and Environmental Research Center \& College of Fisheries and Ocean

14 Sciences, University of Alaska Fairbanks, USA

$15 \quad{ }^{4}$ Alaska Stable Isotope Facility, University of Alaska Fairbanks, USA 
$1 \quad{ }^{5}$ Department of Biological and Environmental Science, University of Jyväskylä,

2 Finland

$3 \quad$ Institute of Oceanology, Polish Academy of Science, Poland

$4 \quad{ }^{7}$ Geological Survey of Finland, Finland

5

6 Corresponding author:

7 Laura Arppe, Laboratory of Chronology, Finnish Museum of Natural History,

8 P.O.Box 64, 00014 University of Helsinki, Finland. Email:

$9 \quad$ laura.arppe@helsinki.fi

11 Abstract

12 The oxygen isotope composition of chironomid head capsules in a sediment

13 core spanning the past 5500 years from lake Svartvatnet in southern

14 Spitsbergen was used to reconstruct the oxygen isotope composition of lake

15 water $\left(\delta^{18} \mathrm{O}\right.$ lw $)$ and local precipitation. The $\delta^{18} \mathrm{O}_{\mathrm{lw}}$ values display shifts from the

16 baseline variability consistent with the timing of recognized historical climatic

17 episodes, such as the Roman Warm Period, the Dark Ages Cold Period and the

18 Little Ice Age. The highest values of the record, ca. $3 \%$ above modern $\delta^{18} \mathrm{O}$ ww 
1 values, occur at ca. 1900-1800 cal. yr BP. Three negative excursions increasing

2 in intensity toward the present, at 3400-3200, 1250-1100 and 350-50 cal. yr BP,

3 are tentatively linked to roughly synchronous episodes of increased glacier

4 activity and general cold spells around the northern North Atlantic. Their

5 manifestation in the Svartvatnet $\delta^{18} \mathrm{Olw}_{\mathrm{lw}}$ record testify to the sensitivity and

6 potential of high Arctic lacustrine $\delta^{18} \mathrm{O}_{\text {chir }}$ records in tracking terrestrial climate

7 evolution, but also highlight nonlinear dynamics within the northern North

8 Atlantic hydroclimatic system. The Little Ice Age period at 350-50 cal. yr BP

9 displays a remarkable $8-9 \%$ drop in $\delta^{18}$ Olw values, construed to predominantly

10 represent significantly decreased winter temperatures during a period of

11 increased seasonal differences and extended sea ice cover inducing changes in

12 moisture source regions.

13 Keywords

14 North Atlantic, Spitsbergen, Svalbard, Arctic, oxygen isotopes, climate,

15 temperature, 'Little Ice Age'

\section{Introduction}

18 The Arctic, and particularly the region of the Nordic Seas has an enormous impact on

19 the global distribution of heat and the ventilation of oceans via interconnected ocean- 
1 atmosphere feedback mechanisms involving surface winds, variable ice conditions,

2 ocean stratification and deep water formation (Bond et al., 2001; McManus et al., 2004;

3 Steffensen et al., 2008). The Svalbard archipelago (Figure 1) lies at the crossroads of the

4 Arctic and North Atlantic Oceans and the major oceanic gateways connecting these, at

5 an optimal position to record past fluctuations in the Arctic ocean-atmosphere system.

6 The four largest islands of the archipelago are the main island Spitsbergen,

7 Nordaustlandet to the northeast, and Edgeøya and Barentsøya to the southeast. As the

8 northernmost extension of the North Atlantic Current, the West Spitsbergen Current

9 carries warm, saline Atlantic water northward along the western coast of Spitsbergen.

10 Cold, ice-laden, low salinity Arctic waters enter the North Atlantic via the western Fram

11 Strait and are delivered south by the East Greenland Current. Additional cold Arctic

12 waters are carried down from the Barents Sea along the eastern margin of Svalbard and

13 around the southern tip of Spitsbergen by the East Spitsbergen Current. The climate of

14 Svalbard is inseparably connected to the variations in the relative strengths of the flow

15 of warm Atlantic and cold Polar/Arctic waters to the region (Marsz, 2013; 

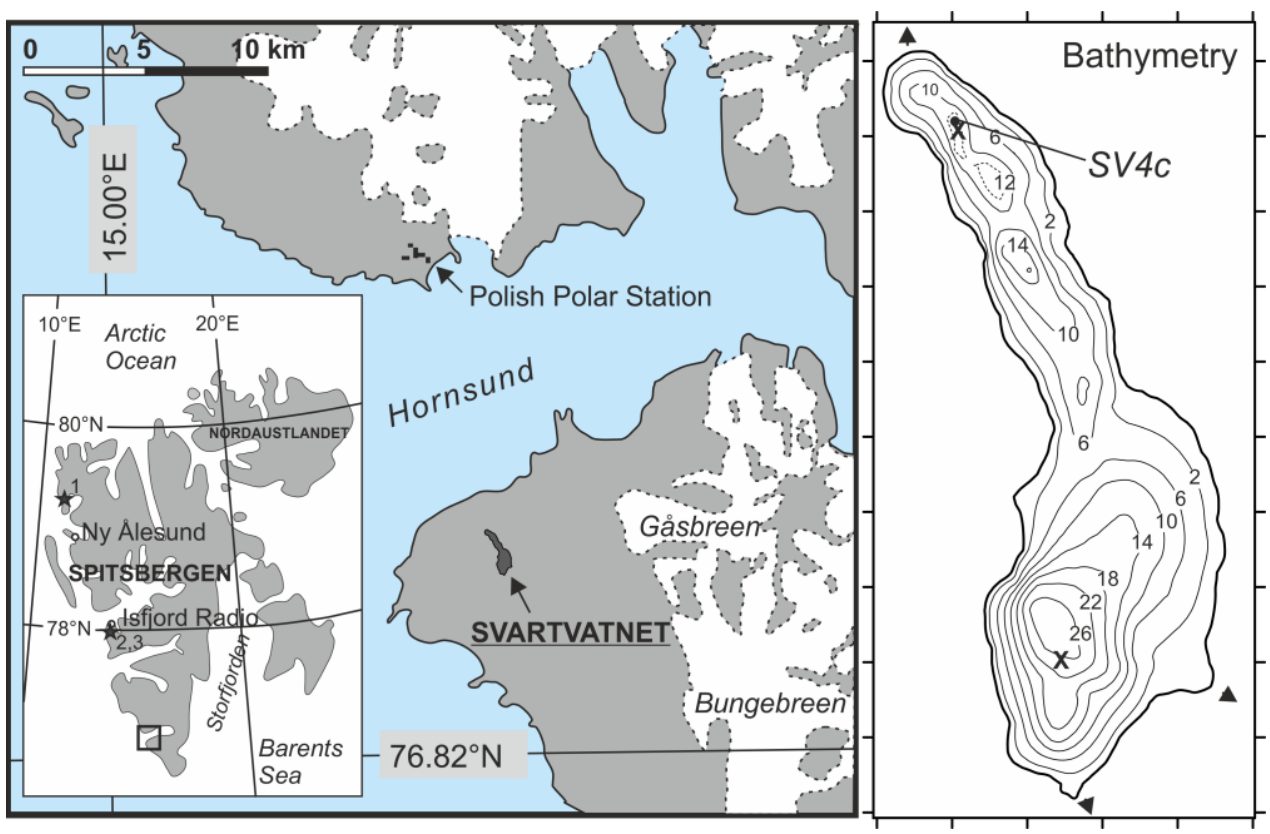

3

4

5

6

7

8

9 The Nordic Seas' significance to global climate is reflected, for example, in the vast

Figure 1: Maps depicting the location of the study area, bathymetry of lake Svartvatnet and locations of the coring site, lake water sampling sites (crosses) and inlet stream sampling sites (triangles). The arrow on the eastern flank shows the approximate location of the outlet stream. Star symbols in the indicator map show sites of prior proxy studies mentioned in the text: 1= Mitrahalv $\phi y a$ a peninsula, $2=$ lake Kongresvatnet, $3=$ lake Skardtjørna.

number of research efforts aiming to characterize and quantify the properties of the

water masses, flow strengths and sea ice conditions in this region during the latest

deglaciation and the Holocene (Belt et al., 2015; Berben et al., 2014; Bonnet et al.,

2010; Cabedo-Sanz and Belt, 2016; De Vernal et al., 2013; Dylmer et al., 2013; Łącka

at al. 2015; Majewski et al., 2009; Moros et al., 2012; Müller et al., 2012; Perner et al., 
1 2015; 2016; Rasmussen et al., 2007; 2012; Rasmussen and Thomsen, 2009; 2014;

2 Risebrobakken et al., 2003; 2010; Sarnthein et al., 2003; Werner et al., 2013; 2014).

3 However, the picture of Holocene terrestrial climatic development on Svalbard is far

4 more limited. Terrestrially based investigations have largely focused on past

5 characteristics and activity of glaciers on Svalbard (Reusche et al., 2014; Snyder et al.,

6 2000; Svendsen and Mangerud, 1991; 1997), with indirect climatic implications.

7 Despite their sensitivity to post-depositional alteration (Pohjola et al., 2002), ice cores

8 from Svalbard glaciers have yielded information on summer and winter temperatures,

9 continentality, sea ice cover and sources of moisture and pollution (Beaudon et al.,

10 2013; Divine et al., 2011; Grinstedt et al., 2006; Isaksson et al., 2005) over the past

11 centuries. However, except for the study of Divine et al. (2011) time series from

12 Svalbard ice caps do not extend back in time beyond 1000 CE. Similarly, millennial

13 timescale reconstructions of climatic variables based on lake sedimentary archives from

14 the region are also very scarce (Birks et al., 1991; D'Andrea et al., 2012; Velle et al.,

15 2010).

16 Environmental time series from terrestrial contexts are highly desirable owing to their

17 potentially higher sensitivity, i.e. possibility for recording shorter lived and smaller

18 scale fluctuations compared to the tendency of short-term variations to be smoothed out

19 in oceanic records. Our study aims to provide a record of the development of the

20 atmospheric component of northern North Atlantic hydroclimate over the mid to late 
1 Holocene from an area extremely sensitive to the interplay of Arctic and Atlantic air

2 masses (Majewski et al., 2009) where previous terrestrial records of climate evolution

3 are very rare. To this end, we use lake sedimentary proxy archives preserving records of

4 the past oxygen isotope values of precipitation $\left(\delta^{18} \mathrm{O}_{\mathrm{pr}}\right)$, which, in the right

5 circumstances can bear information on surface air temperatures (Dansgaard, 1964;

6 Rozanski et al., 1993). Especially at high latitudes, less complexities stemming from

7 moisture recycling and re-evaporation, convection, variable condensation heights and

8 source temperatures disturb the applicability of $\delta^{18} \mathrm{O}_{\mathrm{pr}}$ as a temperature proxy, and much

9 of our understanding of the long term evolution of the thermal climate during the past

800,000 years is based on the isotopic composition of past Arctic and Antarctic

11 precipitation, stored as ice (Johnsen et al., 1997; Jouzel et al., 2007). Also in

12 Spitsbergen, ice core $\delta^{18} \mathrm{O}$ values have been shown to be good proxies for surface air

13 temperature over the last 1000 years (Divine et al., 2011; 2005; Grinsted et al., 2006;

14 Isaksson et al., 2003). Where glacier ice, directly preserving past records of $\delta^{18} \mathrm{O}_{\mathrm{pr}}$, is absent or ice cores are temporally limited by core length as is the case for Spitsbergen, other materials recording the $\delta^{18} \mathrm{O}$ values of environmental waters can be used. One

17 such material is the chitinous exoskeleton of chironomid (Insecta: Diptera:

18 Chrinomidae) larvae. Chironomid remains are generally abundant in lakes and they

19 preserve well in the sediment record (e.g. Brooks, 2006). Chironomid species assemblages, and more recently the $\delta^{18} \mathrm{O}$ values of their larval head capsules, have been 
1 demonstrated as being sensitive indicators of past $\delta^{18} \mathrm{O}_{\mathrm{pr}}$ values and temperatures

2 (Brooks, 2006; Verbruggen et al., 2010a; Wooller et al., 2004). Using oxygen isotope

3 analysis of chironomid head capsules in a lake sediment core retrieved from

4 southernmost Spitsbergen, we aim to reconstruct variations in $\delta 18 \mathrm{O}$ values of lake

5 water $\left(\delta^{18} \mathrm{O}_{\mathrm{lw}}\right)$, and to evaluate how they relate to $\delta^{18} \mathrm{O}_{\mathrm{pr}}$ and changes in past air

6 temperatures. The record spans the past 5500 years and demonstrates how, in optimal

7 circumstances, chironomid $\delta^{18} \mathrm{O}$ values in high Arctic lakes faithfully track climatic

8 oscillations, offering insight into past temperatures and sea ice oscillations.

\section{Study site}

10 Lake Svartvatnet $\left(76.895^{\circ} \mathrm{N}, 15.676^{\circ} \mathrm{E}, 63 \mathrm{~m}\right.$ a.s.l.) is a small, oligotrophic lake in

11 Sørkappland, the sourthern part of Spitsbergen, ca. $1.5 \mathrm{~km}$ south of the Hornsund

12 mouth, and $12 \mathrm{~km}$ south(west) of the Polish Polar Station (Figure 1). It has a surface

13 area of $0.8 \mathrm{~km}^{2}$, a maximum depth of $26.5 \mathrm{~m}$ and a catchment area of ca. $15 \mathrm{~km}^{2}$ (Ojala

14 et al., 2016). The lake comprises a main basin to the south, and a series of smaller,

15 shallower sub-basins in its northern part (Figure 1). Lake Svartvatnet receives water

16 through a network of seasonally active, shallow streams in its northern and southern-

17 southeastern margins, and drains to the adjacent fjord via a single outlet at its

18 southeastern flank. At the time of our surveying in July 2013, the lake water had a

19 temperature between $4{ }^{\circ} \mathrm{C}$ (bottom) and $4.5^{\circ} \mathrm{C}$ (surface), a surface $\mathrm{pH}$ of 7.2 , a color of 0 
$1 \mathrm{CPU}$, conductivity at $50 \mu \mathrm{S} \mathrm{cm}^{-1}$ and total dissolved solids at $20 \mathrm{mg}^{-1}$ (Ojala et al.,

2 2016). Based on turbidity measurements the water column in the northern basin is less

3 turbidic, because the main network of streams entering the lake and delivering

4 allochthonous mineral matter is located in the southern part of the lake. In addition to

5 turbidity measurements, ${ }^{137} \mathrm{Cs}$-based estimates of sediment deposition rate in different

6 parts of the lake indicate that most of the allochtonous material appears to be effectively

7 trapped in the deep southern basin, shielding the northern basins from massive

8 deposition and disturbances by episodic inputs of allochthonous mineral material from

9 seasonal runoff and erosion (Ojala et al., 2016).

10 Lisbetdalen valley, the area surrounding Lake Svartvatnet is a typical periglacial

11 landscape with glacial cirques, stone circles and solifluction tongues. The steep slopes

12 bordering the lake in the west feature talus formations and cones of slided coarse-

13 grained debris. To the north, a series of ancient marine terraces dominate the setting

14 between Lake Svartvatnet and the fjord.

15 The local climate is typical for a high arctic, maritime site. According to monitoring

16 statistics at the Polish Polar Station, the mean annual (MAT) and July air temperatures

17 for $1979-2014$ are $-4.0^{\circ} \mathrm{C}$ and $4.4^{\circ} \mathrm{C}$, respectively, and the mean annual precipitation is

$18438.6 \mathrm{~mm}$ (Institute of Geophysics, Polish Academy of Sciences, 2016). The mean

19 annual and July temperatures for the past five years are distinctly higher, $-1.9^{\circ} \mathrm{C}$ and

$205.2^{\circ} \mathrm{C}$, consistent with observations of a $2-3^{\circ} \mathrm{C}$ increase in seasonal and mean annual 
1 temperatures since 1979 (Marsz, 2013). Precipitation events are strongly linked to

2 advection of warm and moist air from the southwest, and most precipitation falls during

3 the months of August, September and October.

\section{$4 \quad$ Material and Methods}

\section{$5 \quad$ Core sampling and chronology}

6 A $163 \mathrm{~cm}$ long sediment sequence (core SV4c) was taken from the northernmost sub-

7 basin (Figure 1) of lake Svartvatnet in July 2013 with a piston corer. In the laboratory,

8 the core was sliced into $1 \mathrm{~cm}$ sections. The dating of the sediment sequence, consisting

9 of clay gyttja, was established using a combination of radiometric and paleomagnetic

10 methods. A detailed description and discussion regarding the age-depth model for the

11 Svartvatnet sediment sequence depicted in Figure 2, the sediment properties and dating methods was presented by Ojala et al. (2016). The chronology relies on five AMS $-{ }^{14} \mathrm{C}$ dates obtained from terrestrial and aquatic bryophytes, ${ }^{137} \mathrm{Cs}$ and ${ }^{210} \mathrm{~Pb}$ profiles, and comparisons of the paleosecular variation curves to regional reference curves described by Snowball et al. (2007). The resulting age model, constructed using a Bayesian Psequence deposition model in OxCal 4.2 (Bronk Ramsey, 2008; 2009) indicates that the core represents ca. 5500 years of deposition (Ojala et al., 2016). The sediment sequence shows no indication of erosion or slumping of sediment, suggesting stable and continuous sedimentation throughout the sequence, while the ${ }^{210} \mathrm{~Pb}$ record indicates 
1 increased sedimentation during the $20^{\text {th }}$ century. All dates in the text are calendar dates,

2 discussed either as calendar years during the Common Era (CE) or before present (cal.

3 yr BP; present = year 1950), or thousands of years before present (cal. kyr BP).

4

$5 \quad$ Figure 2. The age model for the Svartvatnet sediment core SV4c, modified after Ojala 6 et al. (2016). Data labels show the sample-ID and uncalibrated radiocarbon date.

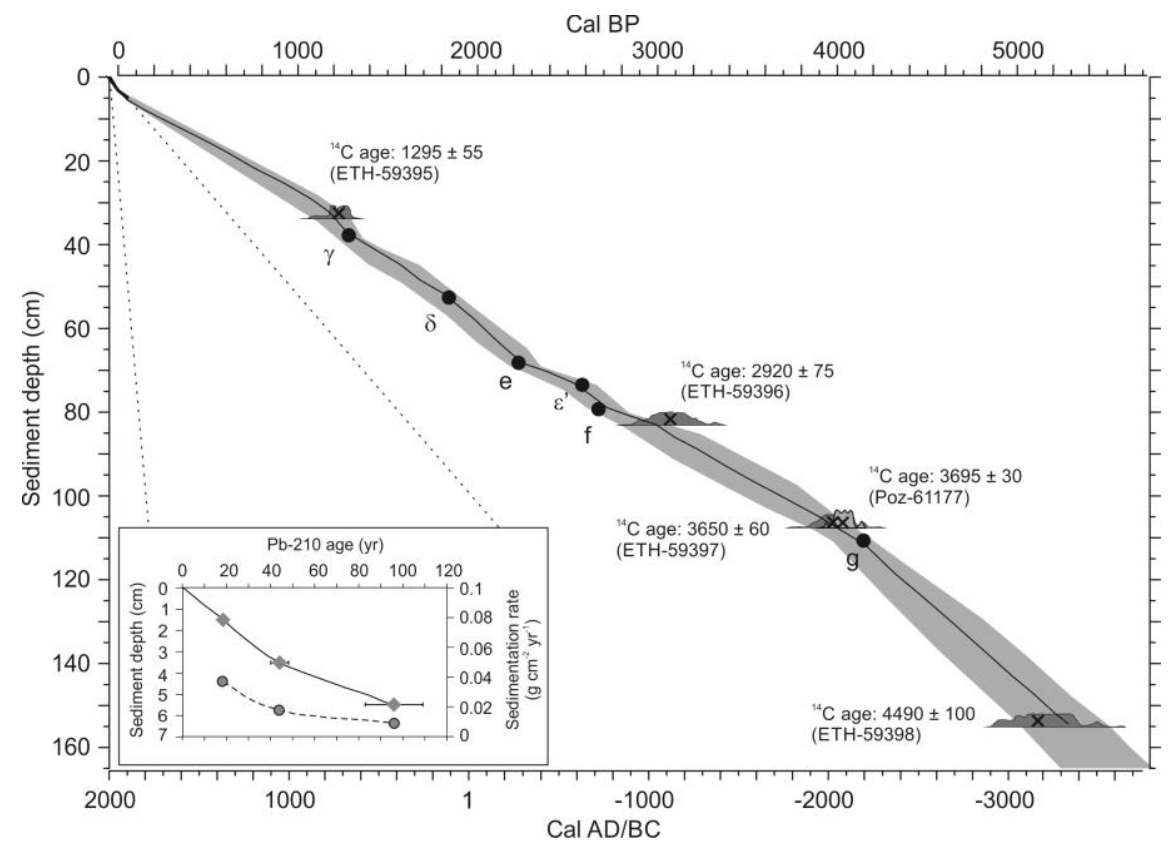

8 Chironomid oxygen isotope analyses

9 The oxygen isotope analysis was performed on mixed chironomid taxa, following

10 Wooller et al. (2004; 2008; 2012) and Verbruggen et al. (2010a). The most abundant

11 chironomid taxa in the sediment were the benthic Micropsectra contracta-type and $M$.

12 radialis-type that occurred throughout the stratigraphy (Luoto et al., in review). The 
1 sampling plan aimed at analyzing $\delta^{18} \mathrm{O}$ values of chironomid larval head capsules

$2\left(\delta^{18} \mathrm{O}_{\text {chir }}\right)$ from $1 \mathrm{~cm}$ thick slices of sediment taken every four centimeters: $0-1 \mathrm{~cm}, 4-5$

$3 \mathrm{~cm}$ etc. However, the number of chironomid head capsules per $\mathrm{cc}$ of sediment was

4 relatively low and varied along the sediment sequence, and in most cases it was

5 necessary to combine two to four adjacent $1 \mathrm{~cm}$ slices in order to achieve a satisfactory

6 sample mass. A minimum mass of $50 \mu \mathrm{g}$ was previously recommended by Verbruggen

7 et al. (2010a; 2010b) and Wang et al. (2008), but we typically achieved $\geq 80 \mu \mathrm{g}$. The

8 analytical protocol followed that described in Wang et al. (2008) and a more detailed

9 description is provided in Kurki (2016). The acid treatment step was left out as

10 Svartvatnet sediment is carbonate-poor and there is some evidence that acids may

11 induce oxygen isotope exchange (Verbruggen et al., 2010a; 2010b).

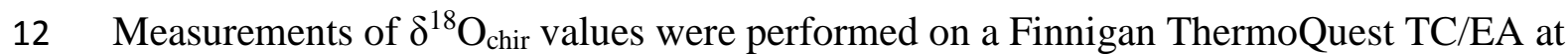
$131330^{\circ} \mathrm{C}$ coupled to a Delta ${ }^{\text {Plus }}$ Advantage isotope ratio mass spectrometer (IRMS) at the 14 Laboratory of Chronology, Finnish Museum of Natural History. Established $\delta^{18} \mathrm{O}$ values 15 for the international reference materials IAEA-NO3 (25.6\%o), IAEA-601 (23.3\%), 16 ANU sucrose (36.4\%o), baleen whale keratin BWBII (14.0\%o), and an internally

17 validated IAEA-CH3 cellulose (32.6\%) were used to normalize raw $\delta^{18} \mathrm{O}$ data. An 18 initial set of four samples was analysed at the Alaska Stable Isotope Facility, where IAEA-601, BWBII and EMA P-1 were run along with the unknowns. Both analytical runs showed a 1:1 relationship and an $\mathrm{r}^{2}>0.99$ for measured vs. expected $\delta^{18} \mathrm{O}$ values of 
1 the references. Chironomid concentration in the sediment sequence did not allow for

2 replicate analysis of unknowns, but reproducibility of similar biogenic reference

3 materials BWBII, Fluka crab shell chitin powder and ANU sucrose indicates a mean

4 analytical precision ( $1 \sigma$ ) of $0.5 \%$, with a range from 0.4 to $2.5 \%$ o depending on signal

5 (sample) size (see Appendix 1). All isotope data are reported as $\delta$-values relative to

6 Vienna Standard Mean Ocean Water (VSMOW).

\section{$7 \quad$ Environmental water samples}

8 To monitor modern $\delta^{18} \mathrm{O}_{\mathrm{pr}}$ values, samples of monthly precipitation were collected at

9 the Polish Polar Station in 2013 and 2014. The sampling protocol strived to minimize

10 any evaporative effects using a layer of paraffin oil in the collection bottles, and melting

11 collected snow in closed containers. In addition, samples of Svartvatnet lake water and

12 three streams supplying the lake were collected in July 2013. Lake water was sampled

13 at the coring location and the southern main basin (Figure 1). The stream waters and

14 lake surface water were collected in $100 \mathrm{ml}$ HDPE flasks filled to the brim and sealed

15 tightly. The subsurface water column was sampled at three levels - 0.9, 6 and $12 \mathrm{~m}$; and

$16 \quad 0.9,10$ and $24 \mathrm{~m}$ for the coring site and southern basin, respectively - using $500 \mathrm{ml}$

17 HDPE flasks in a Biothofen VP90 water sampler.

18 The lake and stream waters, as well as the monthly precipitation samples for Jan-Jun

192013 were analysed for their $\delta^{2} \mathrm{H}$ and $\delta^{18} \mathrm{O}$ values on a Picarro Isotopic H2O L1115-I 
1 cavity ringdown spectrometer at the Department of Geosciences and Geography,

2 University of Helsinki. All samples were measured in duplicate. Two internal reference

3 waters calibrated against VSMOW and SLAP standards were used to normalize the

4 results. Sample duplicates show a mean reproducibility $(1 \sigma)$ of $0.1 \%$ ond $0.2 \%$ for

$5 \quad \delta^{18} \mathrm{O}$ and $\delta^{2} \mathrm{H}$, respectively, while the long-term reproducibility based on standards is

$6 \quad 0.2 \%$ for $\delta^{18} \mathrm{O}$ and $1 \%$ for $\delta^{2} \mathrm{H}$. Precipitation samples from July 2013 to December

72014 were analysed in quadruplicate at the Alaska Stable Isotope Facility on a Delta V

8 Plus IRMS coupled to a ThermoQuest TC/EA pyrolysis unit. To ensure comparability,

9 the same in-house references used at the University of Helsinki were included in the

10 run. Sample replicates showed a mean reproducibility $(1 \sigma)$ of $0.3 \%$ and $2 \%$ for $\delta^{18} \mathrm{O}$

11 and $\delta^{2} \mathrm{H}$ values, respectively.

Reconstructions

13 The $\delta^{18} \mathrm{O}_{\mathrm{lw}}$ values were calculated from the measured $\delta^{18} \mathrm{O}_{\text {chir values using a previously }}$ 14 established calibration based on $\delta^{18} \mathrm{O}$ value pairs $(n=19)$ of chitinous head capsules of 15 chironomid larvae from surface sediment and samples of the ambient lake water along a 16 latitudinal transect extending from 40.9 to $68.4^{\circ} \mathrm{N}$ across Europe, and covering a $\delta^{18} \mathrm{O}_{\mathrm{lw}}$ 17 range from -0.3 to $-13.0 \%$ (Eq. 1; Verbruggen et al., 2011).

$\delta^{18} O_{\text {chir }}=0.76 \times \delta^{18} O_{l w}+21.09 \quad r^{2}=0.90$ 
1 To estimate changes in MAT corresponding to changes in $\delta^{18} \mathrm{O}$ values, we calculated

2 two indexed MAT reconstructions. Both rely on spatial $\delta / T$ relationships (Dansgaard,

3 1964; Rozanski et al., 1993) derived from regressions of long-term means of $\delta^{18} \mathrm{O}$

4 values and MAT along climatic gradients around the Northern North Atlantic. In the

5 first approach, MAT was calculated from $\delta^{18} \mathrm{O}_{\text {chir }}$ values using a calibration by Wooller

6 et al. (2004) correlating $\delta^{18} \mathrm{O}_{\text {chir }}$ values of surface sediment chironomid larval chitin

7 against projected MAT at four lake sites in coastal northeastern North-America and

8 Greenland (Eq. 2). In the second approach, changes in MAT were calculated from

9 changes in reconstructed $\delta^{18} \mathrm{O}_{\mathrm{lw}}$ values, based on the relationship between $\delta^{18} \mathrm{O}_{\mathrm{pr}}$ and

MAT values (IAEA/WMO, 2016) on coastal stations with $\geq 5$ years of observations

11 adjacent to the Greenland Sea, including Spitsbergen (Eq. 3; see Appendix 1 for data).

$\delta^{18} O_{\text {chir }}=0.65 \times M A T+14.5 \quad r^{2}=0.98$

$\delta^{18} O_{p r}=0.71 \times T-9.94 \quad r^{2}=0.83 \quad(E q .3)$

14 The composite error $(1 \sigma)$ factoring in measurement uncertainty and calibration error 15 associated with the reconstructed $\delta^{18} \mathrm{O}_{\mathrm{lw}}$ values, and MAT indices based on Wooller et 16 al. (2004), was quantified for each sample depth using Equation 4, which represents a 17 modification (Pryor et al., pers.comm. 2015) of formula number four presented and discussed in Pryor et al. (2014). Briefly, $x$ is the reconstructed term, $\delta x$ the total error for that term, $y$ is $\delta^{18} \mathrm{O}_{\text {chir, }} \delta y$ is the measurement error for $\delta^{18} \mathrm{O}_{\text {chir, }} a$ is the slope of the 
1 calibration, $S_{y / x}$ estimates the natural variation around the fit, and $n$ is the number of

2 observations in the calibration data set.

$3 \delta x=\sqrt{\left(\left(\frac{S_{y / x}}{a} \sqrt{\frac{1}{n}+\frac{(y-\bar{y})^{2}}{a^{2} \sum\left(x_{i}-\bar{x}\right)^{2}}}\right)^{2}+\left(\frac{\delta y}{a}\right)^{2}\right)}$

4 For the temperature estimates based on the Greenland Sea $\delta / T$ gradient, the composite

5 errors were calculated using the formula for Z2-type conversions (Pryor et al., 2014).

6 Throughout the text, the composite errors are given in parentheses, in contrast to

7 measurement precision and standard deviation around calculated mean values.

\section{Results}

9 The $\delta^{18} \mathrm{O}_{\text {chir }}$ values range from 6.9 to $16.3 \%$ (Appendix 1). The lowest values in the

10 sequence are recorded for sample depths 6-7 $\mathrm{cm}$ and 8-12 cm, and the highest at 52-53

$11 \mathrm{~cm}$, corresponding to ca. 350-50 cal. yr BP and 1900-1800 cal. yr BP, respectively,

12 according to the age model (Ojala et al., 2016). Two additional noteworthy negative

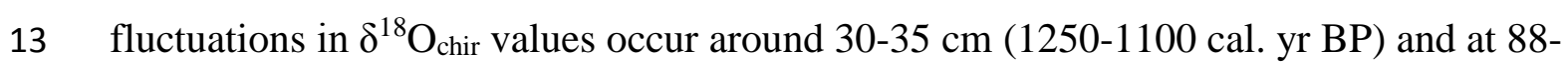

$1492 \mathrm{~cm}\left(3400-3200 \mathrm{cal}\right.$. yr BP). Outside these perturbations, the rest of the $\delta^{18} \mathrm{O}_{\text {chir }}$ record

15 is relatively stable, with most samples exhibiting values between ca. -14.5 to $-12 \%$. 

sampled in July 2013.

\begin{tabular}{lcccl}
\hline & depth & $\begin{array}{c}\boldsymbol{\delta}^{18} \mathbf{O}(\%, \\
\text { VSMOW) }\end{array}$ & $\begin{array}{c}\boldsymbol{\delta}^{2} \mathbf{H}(\%, \\
\text { VSMOW) }\end{array}$ & d-excess \\
\hline Northern basin & surface & -9.6 & -67 & 9.8 \\
& $0.9 \mathrm{~m}$ & -9.8 & -67 & 11.4 \\
& $6 \mathrm{~m}$ & -9.7 & -66 & 10.8 \\
Southern basin & $12 \mathrm{~m}$ & -9.5 & -66 & 10.0 \\
& surface & -9.4 & -65 & 9.6 \\
& $0.9 \mathrm{~m}$ & -9.5 & -66 & 9.5 \\
lake average & $10 \mathrm{~m}$ & -9.4 & -66 & 9.6 \\
& $24 \mathrm{~m}$ & -9.6 & -67 & 10.4 \\
Stream 1, south & & $-9.6 \pm 0.1$ & $-66 \pm 0.5$ & \\
Sream 2, southeast & & -9.3 & -66 & 8.6 \\
Stream 3, north & & -8.8 & -61 & 9.1 \\
stream average & & -8.0 & -55 & 9.0 \\
\hline
\end{tabular}

3

4 The oxygen and hydrogen isotopic compositions of the environmental waters in the

5 study area are presented in Tables 1 and 2. The lake is not isotopically stratified, and the

6 water column shows uniform $\delta^{18} \mathrm{O}_{\mathrm{lw}}$ and $\delta^{2} \mathrm{H}_{\mathrm{lw}}$ values at $-9.6 \% \pm \pm 0.1$ and $66 \%$ \pm 0.5 ,

7 respectively. The inlet stream waters show more variability, with $\delta^{18} \mathrm{O}$ and $\delta^{2} \mathrm{H}$ values

8 of $-8.7 \%$ \pm 0.6 and $-61 \%$ \pm 5 , respectively. The monthly precipitation samples collected

9 at the Polish Polar Station $14 \mathrm{~km}$ northeast of the study lake indicate a mean annual

$10 \delta^{18} \mathrm{O}_{\mathrm{pr}}$ value of $-8.7 \%$ for 2013 , and $-7.6 \%$ for 2014 . Mean monthly values of $\delta^{18} \mathrm{O}_{\mathrm{pr}}$

11 over the 2013-2014 period were related to air temperature (Institute of Geophysics,

12 Polish Academy of Sciences, 2016) according to $\delta^{18} \mathrm{O}_{\mathrm{pr}}=0.47 * \mathrm{~T}_{\mathrm{air}}-7.07\left(\mathrm{r}^{2}=0.66\right)$. 
1 Using the station's records of monthly precipitation amount for the collection period,

2 we calculated amount-weighted annual mean $\delta^{18} \mathrm{O}_{\mathrm{pr}}$ values of $-7.2 \%$ and $-7.4 \%$ for

32013 and 2014, respectively.

$4 \quad$ Table 2. The isotope composition of monthly samples of precipitation collected

5 at the Hornsund Polish Polar Station 2013-2014.

6

\begin{tabular}{|c|c|c|c|c|c|c|}
\hline & \multicolumn{3}{|c|}{$\delta^{18} \mathrm{O}(\%,$, VSMOW) } & \multicolumn{3}{|c|}{$\delta^{2} H(\%$, VSMOW) } \\
\hline & 2013 & 2014 & 2-yr mean* & 2013 & 2014 & 2-yr mean* \\
\hline January & -8.8 & -4.6 & -6.7 & -56 & -19 & -37 \\
\hline February & -10.8 & - & -10.8 & -76 & - & -76 \\
\hline March & -10.2 & -11.6 & -10.9 & -69 & -89 & -79 \\
\hline April & -11.9 & -11.7 & -11.8 & -90 & -73 & -82 \\
\hline May & -8.1 & -7.8 & -7.9 & -59 & -51 & -55 \\
\hline June & -1.2 & -4.2 & -2.7 & -6 & -33 & -20 \\
\hline July & - & -3.5 & -3.5 & - & -29 & -29 \\
\hline August & -7.2 & -7.4 & -7.3 & -61 & -62 & -62 \\
\hline September & -4.9 & -6.2 & -5.5 & -42 & -49 & -46 \\
\hline October & -9.3 & -9.2 & -9.2 & -69 & -73 & -71 \\
\hline November & -9.3 & -6.2 & -7.7 & -65 & -51 & -58 \\
\hline December & -13.5 & -11.5 & -12.5 & -84 & -83 & -84 \\
\hline mean annual* & -8.7 & -7.6 & & -62 & -56 & \\
\hline mean ann. w. ** & -7.2 & -7.4 & & -55 & -56 & \\
\hline
\end{tabular}

* arithmetic mean

** amount weighted mean annual value, see Results

7

8 The reconstructed sequence of lake Svartvatnet $\delta^{18} \mathrm{O}_{\mathrm{lw}}$ values (Figure 3a, Appendix 1)

9 logically tracks the pattern of the $\delta^{18} \mathrm{O}_{\text {chir }}$ record, but is shifted to more negative values

10 by $23.6 \% \pm \pm 0.6$ due to known biogenic fractionation effects between growth water and

11 the chironomid head capsules (see Wang et al., 2009). Thus, the reconstructed $\delta^{18} \mathrm{O}_{\mathrm{lw}}$ 
1 values range from $-18.7 \%$ o $( \pm 2.4)$ to $-6.3 \%$ ( $( \pm 1.5)$, the values in parentheses

2 representing the composite error (c.f. Pryor et al., 2014, see Methods). The $\delta^{18} \mathrm{O}_{1 \mathrm{w}}$ value

3 for the top $2 \mathrm{~cm}$ of sediment, reflecting the average composition of lake Svartvatnet

4 water for the past 20 years (Ojala et al., 2016), is $-9.2 \%( \pm 1.9)$.

\section{Discussion}

\section{$6 \quad \delta^{18} O_{1 w}$ reconstruction}

7 Approximately $70 \%$ of the oxygen in chironomid larvae is derived from growth water

8 (Wang et al, 2009). The primary dependence of $\delta^{18} \mathrm{O}_{\text {chir }}$ values on $\delta^{18} \mathrm{O}_{\text {lw }}$ has been

9 demonstrated in field studies (Wooller et al. 2004; Verbruggen et al 2010a, 2011), and

10 possible changes in, e.g., the relative contributions of different dietary sources and

11 changes in their respective oxygen isotope fractionation systematics appear subordinate

12 to the influence of ambient water, as observed by Wooller et al. (2008) in a study

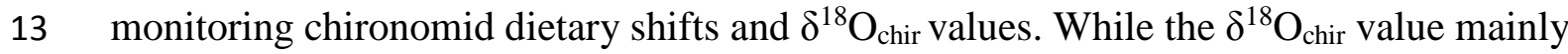

14 tracks the $\delta^{18} \mathrm{O}$ value of lake water, the reliability of the $\delta^{18} \mathrm{O}_{\mathrm{lw}}$ reconstruction is

15 influenced by the applicability of the $\delta^{18} \mathrm{O}_{\text {chir }}-\delta^{18} \mathrm{O}_{\text {lw }}$ equation describing the oxygen

16 isotope fractionation between lake water and chironomid head capsules. The $\delta^{18} \mathrm{O}_{\text {chir }}$ -

$17 \delta^{18} \mathrm{O}_{\mathrm{lw}}$ equation applied here (Verbruggen et al., 2011) might prove unsuitable in case of

18 a significant dependence of fractionation effects on 1) formation temperature, or 2)

19 species of chironomid analysed. Contrary to what is observed for the formation of many 
1 carbonates and silicates, a direct temperature dependence of the O-isotope fractionation

2 during chironomid head capsule biosynthesis is not expected (Wolfe et al., 2001; Heiri

3 et al., 2012; Verbruggen et al., 2010a; 2011) but this remains to be experimentally

4 verified. Temperature dependent fractionation would be problematic in circumstances of

5 marked water temperature differences between the calibration conditions and those at

6 the study lake. Unfortunately Verbruggen et al. (2011) do not report the temperatures of

7 their lake profundal waters where chironomids live, but they sampled very deep lakes

8 whose bottom water temperatures are likely to remain stable and relatively low.

9 We followed the technique of previous down-core chironomid $\delta^{18} \mathrm{O}$ investigations in

10 relying on a mixed-taxon approach (Verbruggen et al., 2010a; Wooller et al., 2004;

$112008 ; 2012)$, which was also applied in the $\delta^{18} \mathrm{O}_{\text {chir }}-\delta^{18} \mathrm{O}_{\mathrm{lw}}$ calibration of Verbruggen et

12 al. (2011). The notable similarity of $\delta^{18} \mathrm{O}_{\mathrm{lw}}$ reconstructions for Lake Rotsee in

13 Switzerland based on lake carbonates and mixed-taxon $\delta^{18} \mathrm{O}_{\text {chir }}$ values (Verbruggen et al., 2010a) indicates that different chironomid taxa exhibit very similar relationships to ambient $\delta^{18} \mathrm{O}_{\mathrm{lw}}$ values and mixing species for the purpose of estimating past $\delta^{18} \mathrm{O}_{\mathrm{lw}}$ values does not induce significant errors in the reconstruction. Further, the observation

17 of Wooller et al. (2008) that marked changes in $\delta^{18} \mathrm{O}_{\text {chir values along a Holocene- }}$ covering sediment sequence from an Icelandic lake were not coeval with shifts in chironomid taxonomic assemblages supports this conclusion. 
1 As an additional sensitivity test, we applied another $\delta^{18} \mathrm{O}_{\text {chir }}-\delta^{18} \mathrm{O}_{\mathrm{lw}}$ calibration from a

2 rearing experiment relating $\delta^{18} \mathrm{O}$ values of whole bodies of Chironomus dilutus larvae to

3 that of their growth water (Wang et al., 2009) to estimate past $\delta^{18} \mathrm{O}_{\mathrm{lw}}$ values for lake

4 Svartvatnet. The Wang et al. (2009) equation $\left(\delta^{18} \mathrm{O}_{\text {chir }}=0.69 * \delta^{18} \mathrm{O}_{\mathrm{w}}+20.1\right)$ is very

5 similar to that of Verbruggen et al. (2011) despite obvious differences in study set-ups,

6 and the reconstructed $\delta^{18} \mathrm{O}_{\mathrm{lw}}$ records are likewise highly comparable (Figure 3a). This

7 points to relative insensitivity of the stable oxygen isotope fractionation to any potential

8 species specific vital effects and possible differences in dietary source and water

9 temperature, and further suggests a negligible offset between the isotope composition of

10 chironomid larval chitinous head capsules and that of the whole body, as already

11 observed for carbon and nitrogen isotopes (Heiri et al., 2012). Consequently, based on

12 these observations and the fact that the measured present-day lake Svartvatnet $\delta^{18} \mathrm{O}_{\mathrm{lw}}$

13 value, $9.6 \% \pm 0.1$, is well within the $\delta^{18} \mathrm{O}_{\text {lw }}$ estimate for the top $2 \mathrm{~cm}$ of surface

14 sediment, $-9.2 \%$ o $( \pm 1.9)$, we consider our $\delta^{18} \mathrm{O}_{\mathrm{lw}}$ reconstruction a realistic, robust

15 representation of past changes in the oxygen isotope composition of lake Svartvatnet

16 water. 


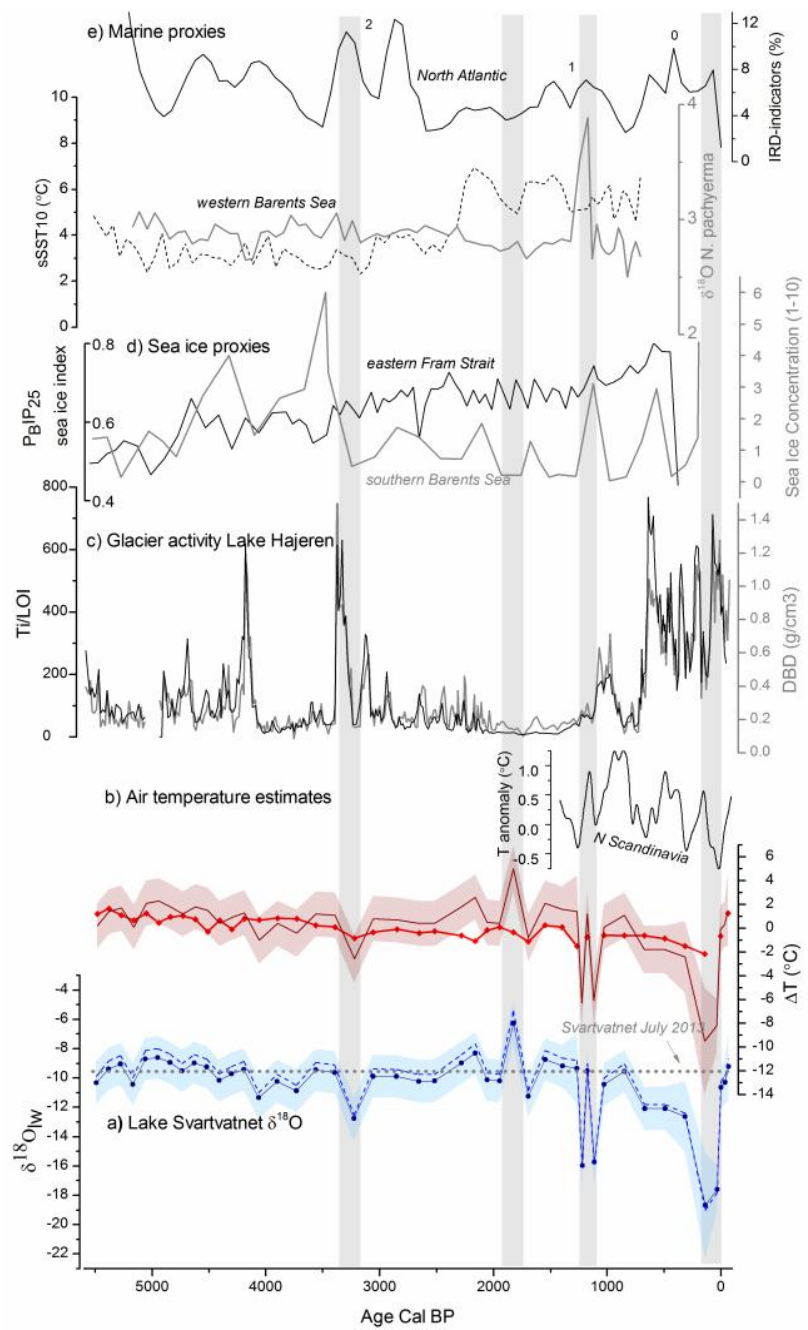

Figure 3: Proxy records of Arctic climate. a) Lake Svartvatnet $\delta^{18} \mathrm{O}$ values calculated according to Verbruggen et al. (2011; solid line with markers) and Wang et al. (2009; dashed line). Shading represents the composite error of the reconstruction calculated based on Verbruggen et al. (2011). b) Air temperature reconstructions. Solid thin line and shading (composite error) shows calculated $\triangle M A T$, assuming all variability in $\delta^{18} O_{l w}$ stems from changes in temperature. Solid bold line with markers depicts the $\triangle J$ July-T reconstruction based on chironomid assemblage analysis from the same core (Luoto et al., in review.) Both reconstructions are expressed as deviations from the reconstruction mean. Additionally shown is the 100 yr-filtered reconstruction of summer temperature anomalies from Lake Torneträsk, northern Scandinavia, for the past 1500 years (Grudd, 2008). c) Sedimentary records of glacier activity from lake Hajeren on Mitrahalvфya, western Spitsbergen (Van der Bilt et al., 2015). d) Indicators of sea ice conditions in the eastern Fram Strait (Müller et al., 2012) and southeastern Barents Sea (De Vernal et al., 2013). e) Reconstructed summer sea surface (upper $10 \mathrm{~m}$ ) temperature and $\delta^{18} \mathrm{O}$ values of $\mathrm{N}$. pachyderma (sin) from the western Barents Sea (Sarnthein et al., 2003), and a stacked record of Ice 
1 Rafted Debris indicators from four cores in the North Atlantic, with numbers referring to Bond Cycles 0

2 through 2 (Bond et al., 2001).

3

$4 \quad \delta^{18} \mathrm{O}_{\text {w }}$ as a proxy for $\delta^{18} \mathrm{O}_{\mathrm{pr}}$

5 The $\delta^{18} \mathrm{O}$ value of lake water can be expected to represent the mean $\delta^{18} \mathrm{O}$ value of

6 precipitation in the catchment area if it is not altered by evaporation, or does not receive

7 significant input from non-local or non-contemporaneous waters, like melt waters from

8 high altitudes or glaciers. Presently, the nearest glaciers Gåsbreen and Bungebreen lie 5-

$97 \mathrm{~km}$ to the east and southeast of the lake (Figure 1), and the chain of highest peaks in

10 Sørkappland reaching $925-142 \mathrm{~m}$ a.s.l. is ca. $11 \mathrm{~km}$ to the east. Our study lake is also

11 shielded from the drainage of both glaciers and high altitude peaks by a N-S trending

12 ridge of higher (ca. $400-500 \mathrm{~m}$ a.s.l.) ground. The $\delta^{18} \mathrm{O}$ values of the southern inlet

13 streams (-9.3 and $-8.8 \%$, Table 1) draining these higher terrains are close to mean

14 annual values of $\delta^{18} \mathrm{O}_{\mathrm{pr}}$ and probably represent a mixture of June-July precipitation and

15 the continued seasonal melt of snow from the slopes in the lake catchment area.

16 Lake Svartvatnet has a relatively small volume compared to the size of its catchment

$17\left(\sim 15 \mathrm{~km}^{2}\right)$, suggesting a relatively short residence time with the majority of the water

18 mass replaced each year during snow melt. The short, ca. 2.5 month, period of time the

19 lake remains free of ice cover annually, the generally low temperatures and high relative humidity (July 2013-2014 mean RH 87\%) of the local air during the open-water period 
1 minimize evaporative influences to the water body. At the time of sampling in mid-July

2 the water column shows uniform $\delta^{18} \mathrm{O}$ values, with no indication of surface water ${ }^{18} \mathrm{O}$

3 enrichment, which would otherwise indicate significant evaporation from the lake

$4 \quad$ surface (Table 1). Furthermore, the $\delta^{18} \mathrm{O}$ and $\delta^{2} \mathrm{H}$ values of the samples collected from

5 Svartvatnet lake water and the inlet streams plot along the local meteoric water line

6 (Figure 4) describing the isotopic composition of precipitation on the western coast of

7 Spitsbergen.

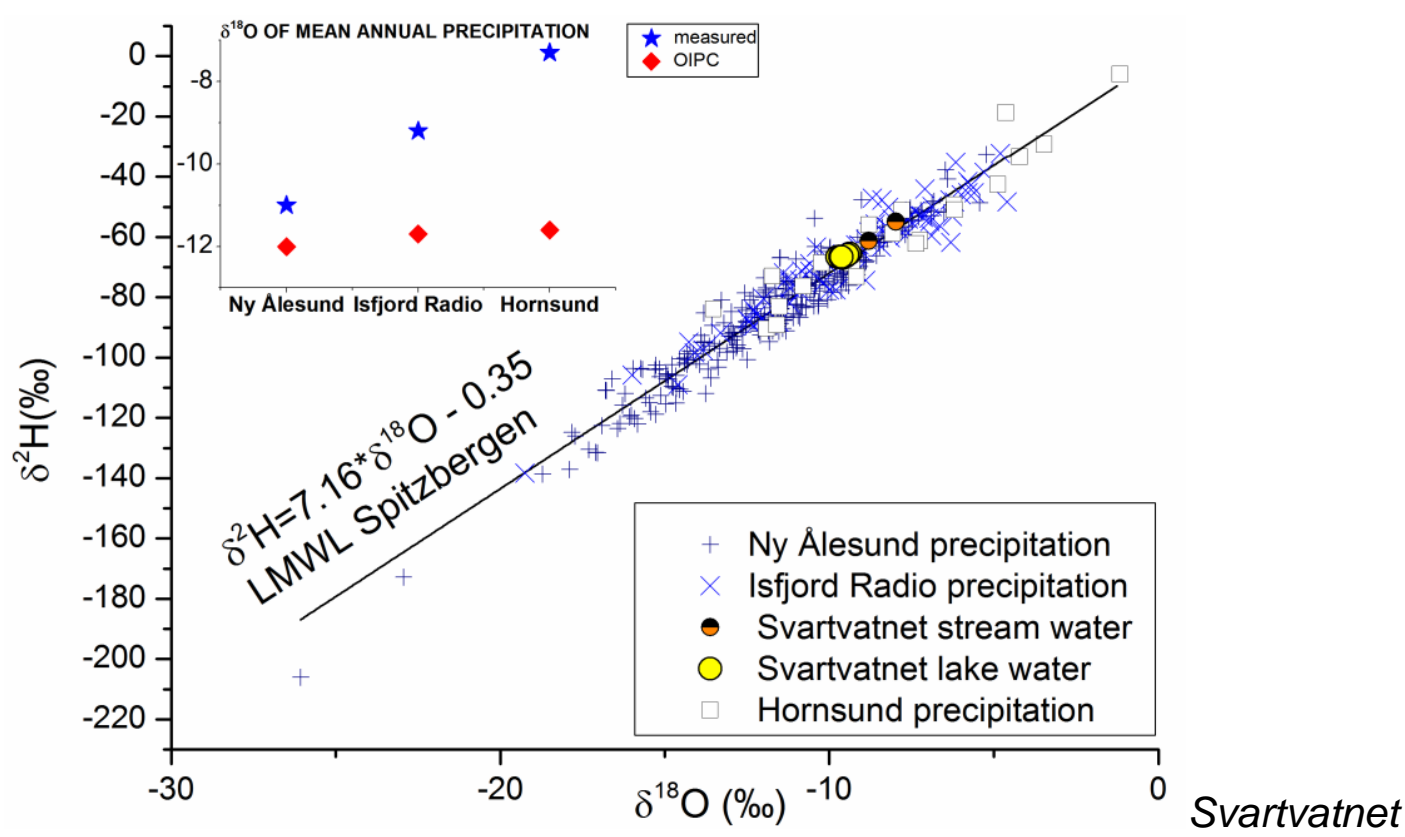

$9 \quad$ Figure 4: The $\delta^{18} \mathrm{O}$ and $\delta^{2} \mathrm{H}$ values of the water samples taken from lake Svartvatnet, inlet streams and 10 monthly precipitation relative to the Local Meteoric Water Line for western Spitsbergen. Inset:

11 comparison between amount weighted mean annual $\delta^{18} O$ values of precipitation in Ny Ålesund, Isfjord

12 Radio and Hornsund and those predicted by the Online Isotopes in Precipitation Calculator (OIPC;

13 Bowen, 2016; Bowen and Revenaugh, 2003). 
1 These data strongly suggest that the waters of lake Svartvatnet are sourced from local

2 precipitation and evaporative isotopic enrichment is likely to be negligible. However,

3 the isotopic composition of lake Svartvatnet water in mid-July 2013 was $\sim 2 \%$ lower

4 than the amount-weighted mean annual $\delta^{18} \mathrm{O}_{\mathrm{pr}}$ values for $2013-2014$ recorded at the

5 Polish Polar Station. There are several possible explanations for this observation. The

6 difference may be a reflection of the considerable uncertainties in precipitation amount

7 measurements at high latitudes (Aguado and Burt, 1999; Łupikasza, 2013) affecting the

8 amount weighted $\delta^{18} \mathrm{O}_{\mathrm{pr}}$ values. According to Aguado and Burt (1999) Spitsbergen is

9 located in a zone where the error may reach $20-39 \%$ of measured annual totals, with totals of snowfall having the highest potential errors (Łupikasza, 2013). Furthermore,

11 the discrepancy may be related to the fact that autumn 2012 was not covered in the

12 precipitation monitoring, although it can be expected to exert a major control over

$13 \delta^{18} \mathrm{O}_{\mathrm{lw}}$ values of the lake sampled in July 2013, considering that the autumn months

14 usually contribute almost $40 \%$ of annual precipitation (Lupikasza, 2013). Another factor

15 that could explain the offset is the general seasonal variation of $\delta^{18} \mathrm{O}_{\mathrm{pr}}$ values. The

16 degree to which lake water $\delta^{18} \mathrm{O}$ values are affected by seasonal variability in $\delta^{18} \mathrm{O}_{\mathrm{pr}}$ is

17 determined by the residence time (e.g., Sauer et al., 2001). The relatively short

18 residence time of lake Svartvatnet gives cause to expect that $\delta^{18} \mathrm{O}_{\mathrm{lw}}$ values are at their

19 lowest during the summer snowmelt period, usually beginning in late May to early June in this region (Rotschky et al., 2011), and rise gradually towards the end of the open 
1 water season (September; Ojala et al., 2016) with the accumulation of warm-season

2 precipitation with higher $\delta^{18} \mathrm{O}$ values.

3 We note that the $\delta^{18} \mathrm{O}_{\mathrm{lw}}$ values are ca. $2.5 \%$, and the amount weighted annual $\delta^{18} \mathrm{O}_{\mathrm{pr}}$

4 values ca. $4.5 \%$ less negative than what the Online Isotopes in Precipitation Calculator

5 (OIPC; Bowen, 2016; Bowen and Revenaugh, 2003) predicts for the site based on its

6 location and elevation (see inset in Figure 4). Positive offsets of 1\%o and 2.5\%o are

7 observed also for amount weighted annual $\delta^{18} \mathrm{O}_{\mathrm{pr}}$ values on IAEA's Global Network of

8 Isotopes in Precipitation monitoring stations at Ny Ålesund and Isfjord Radio

9 (IAEA/WMO, 2016), respectively, suggesting that the OIPC tends to underestimate

$10 \delta^{18} \mathrm{O}_{\mathrm{pr}}$ values for this region, and might not be a suitable point of reference for local

$11 \delta^{18} \mathrm{O}_{\mathrm{pr}}$ values.

12 Viewed against this background, it is reasonable to assume that lake Svartvatnet $\delta^{18} \mathrm{O}_{\mathrm{lw}}$

13 values track changes in mean annual $\delta^{18} \mathrm{O}$ values of regional precipitation. It is also

14 likely, that they represent the absolute level of $\delta^{18} \mathrm{O}_{\mathrm{pr}}$ values with reasonable accuracy,

15 with a possible bias towards somewhat lower $\delta^{18} \mathrm{O}$ values due to lingering effects of

16 summer snow melt during the period of chironomid larval growth. However, to

17 reconstruct past environmental conditions, we must be able to assume that the status

18 quo regarding evaporation and glacier water influence to $\delta^{18} \mathrm{O}_{\mathrm{lw}}$ has remained

19 unchanged for the past 5500 years. Based on the modest increases in temperatures

20 inferred for the warmer early Holocene period in Svalbard (Birks, 1991) any significant 
1 increase in evaporative demand is not expected. Also, there is no geomorphological

2 evidence for presence of a glacier in the Lisbetdalen valley during the late Holocene

3 (Lindner and Marks, 1993; Ojala et al., 2016), and records of glacier thickness since

41899 (Ziaja, 2004), immediately after the LIA when Svalbard glaciers in general are

5 thought to have had their largest Holocene extent (Snyder et al., 2000; Svendsen and

6 Mangerud 1997; Werner 1993), suggest that the nearest glacier Gåsbreen did not

7 advance over the ca. $\geq 400 \mathrm{~m}$ a.s.l. ridge separating it from lake Svartvatnet catchment.

8 Thus it seems plausible that lake Svartvatnet has remained shielded from glacier melt

$9 \quad$ water pulses even during (after) intervals of expanded glacier extent.

\section{Reconstructing paleoenvironmental conditions}

11 Some noteworthy challenges arise when attempting to interpret $\delta^{18} \mathrm{O}_{\mathrm{pr}}$ proxy records in terms of past air temperatures. An exhaustive review of these is beyond this paper, but we briefly visit some of the most relevant issues. Ideally, investigations of variations in past temperatures based on $\delta^{18} \mathrm{O}_{\mathrm{pr}}$ proxies should rely on temporal $\delta / \mathrm{T}$ slopes, based on prior knowledge of the regional past relationship between changes in past surface temperature and $\delta^{18} \mathrm{O}_{\mathrm{pr}}$, derived from, for example, paleogroundwaters (Darling et al., 1997; Huneau et al., 2002; Loosli et al., 2001) or ice cores (Buizert et al., 2014; Jouzel et al., 1997; Vinther et al., 2008). Situations with independent knowledge of both MAT and $\delta^{18} \mathrm{O}_{\text {pr }}$ changes are, however, regrettably rare, and most paleotemperature studies apply spatial $\delta / T$ slopes determined over large-scale geographical climatic gradients 
1 (Dansgaard, 1964; Rozanski et al., 1992; 1993). Despite several reports of temporal $\delta / T$

2 slopes close to modern spatial slopes from both North-America and Europe (Beyerle et

3 al., 1998; Edwards et al., 1996; Hammarlund, 1999; Remenda et al., 1994; Rozanski et

$4 \quad$ al., 1992; Zuber et al., 2004), contradicting observations of temporal $\delta / T$ slopes in

5 Greenland different from modern spatial gradients (Buizert et al., 2014; Jouzel et al.,

6 1997; Vinther et al., 2008) add considerable uncertainty to the general reliability of

$7 \quad \delta^{18} \mathrm{O}_{\mathrm{pr}}$ values as proxy for temperature.

8 The $\delta^{18} \mathrm{O}$ value of precipitation, and thus, the observed $\delta / \mathrm{T}$ slope, is a manifestation of

9 the isotopic composition and conditions at the source of evaporation, and conditions

10 along the moisture trajectories to the site of precipitation. Therefore a change in the

11 dominant moisture source or its temperature, affecting the extent of fractionation of the

12 water vapour (Dansgaard, 1964), can lead to a change in the $\delta^{18} \mathrm{O}$ of precipitation at a

13 site (Masson-Delmotte et al., 2005; Steffensen et al., 2008; Vachon et al., 2010). For

14 example Masson-Delmotte et al. (2005) explained the lower $\delta^{18} \mathrm{O}$ values of the NGRIP

15 ice core compared to the GRIP record by a combination of lower condensation

16 temperatures and a different moisture source with a higher temperature. In the Arctic,

17 sea ice acts as insulation between the ocean and the atmosphere restricting the exchange

18 of moisture and heat, and has been shown to exert a significant influence over the

19 availability of and distance to moisture sources (Divine et al., 2008; Grinsted et al.,

20 2006; Klein et al., 2015). According to a recent simulation examining the effects of 
1 changes in sea ice cover and sea surface temperatures on $\delta^{18} \mathrm{O}$ values of Arctic

2 precipitation, especially the restriction imposed by increased sea ice to locally sourced

3 water vapour causes significant decreases in the $\delta^{18} \mathrm{O}_{\mathrm{pr}}$ values (Faber et al., 2016).

4 Interestingly though, the study reported fairly robust $\delta /$ T relationships, largely

5 unaffected by sea ice variability, around the Arctic.

$6 \quad \delta^{18} \mathrm{O}_{\text {pr }}$ proxies relying on modern spatial $\delta / \mathrm{T}$ relationships will also lead to

7 misinterpretation of air temperatures in cases where the seasonal distribution of

8 precipitation is different from that of the present day. For instance, Wooller et al. (2008)

9 interpreted seasonality changes as a contributing factor explaining large $\delta^{18} \mathrm{O}$ shifts

10 leading to unrealistically large interpreted temperature changes in an Icelandic

11 lacustrine sediment record covering the Holocene.

Comparisons to other high Arctic proxy records

5500-2500 cal. yr BP. As a whole, the earlier part of the $\delta^{18} \mathrm{O}_{\mathrm{lw}}$ record up to ca. 2500

cal. yr BP shows relatively little variation and the $\delta^{18} \mathrm{O}_{\mathrm{lw}}$ values remain close to presentday level, suggesting fairly stable hydroclimatic conditions similar to those prevailing today. At ca. $3400-3200$ cal. $y r$ BP, the $\delta^{18} \mathrm{O}_{\text {lw }}$ of lake Svartvatnet decreases to $-12.8 \%$, representing the lowest value in the earlier part of the record. The timing of this episode of ca. $3 \%$ lower $\delta^{18} \mathrm{O}_{\mathrm{lw}}$ values is concurrent with a prominent centennial-scale glacier advance at 3380-3230 cal. yr BP on Mitrahalvøya Peninsula in northwestern 
1 Spitsbergen (Figure 3c; Van der Bilt et al., 2015), attributed to North Atlantic forcing

2 against a background of general Neoglacial cooling. In a wider context, the drop

3 overlaps with the timing widespread evidence of increased Northern Hemisphere glacier

4 activity (3.3-2.8 cal. kyr BP; Solomina et al., 2015) and low temperatures (3.3-2.5 cal.

5 kyr BP; Wanner et al., 2011), as well as increased ice rafted debris indicators (Figure

$63 \mathrm{e}$; Bond et al., 2001) and sediment markers of storminess and/or brine formation (ca.

7 3500-3200 cal. yr BP; Sarnthein et al., 2003) indicating cool conditions in the northern

8 North Atlantic.

92500 cal. $y r$ BP to the LIA. After ca. 2500 cal. yr BP the $\delta^{18} \mathrm{O}_{\mathrm{lw}}$ record shows more

10 variability, in agreement with observations of more unstable conditions in the Nordic

11 Seas (Berben et al., 2014; Rasmussen et al., 2012; Risebrobakken et al., 2010) and

12 higher glacier activity around Svalbard (Lubinski et al., 1999; Røthe et al., 2015) towards the end of the Holocene. The highest $\delta^{18} \mathrm{O}_{\mathrm{lw}}$ value of the record occurs at ca. 1900-1800 cal. yr BP ( 50-150 CE), coinciding with a period of general warmth referred to as the Roman Warm Period (RWP). In the North Atlantic Ocean the RWP interval (ca. 2500-1500 cal. yr BP) is associated with, e.g., increased temperatures and

17 productivity, decreased evidence of ice, and strengthened flow along the major flow path and the side branches of the North Atlantic Current (Bianchi and McCave, 1999; Dylmer et al., 2013; Moros et al., 2012; Perner et al., 2015; 2016; Risebrobakken et al., 2003, Sarnthein et al., 2003). Similarly, Northern Hemisphere terrestrial environments 
1 widely display evidence of elevated temperatures between 1-300 CE (Ljungqvist, 2 2010).

3 The prominent double decrease in the Svartvatnet $\delta^{18} \mathrm{O}_{\mathrm{lw}}$ record at ca. $1250-1100$ cal. yr

4 BP suggests that southern Spitsbergen experienced a significant late Holocene cold spell

5 prior to the onset of the LIA. These negative shifts overlap with the latter part of a

6 cooling known as the Dark Ages Cold Period (DACP, ca. 1500-1000 cal. yr BP;

7 Bianchi and McCave, 1999; McDermott et al., 2001). The event is directly preceded by

8 a minimum in total solar irradiation (Renssen et al., 2006; Steinhilber et al., 2009), and

9 contemporaneous with records of expanded glaciers on the Northern Hemisphere at 1.2-

101.1 cal. kyr BP (Solomina et al., 2015). On Spitsbergen, glacier advances or increased

11 glacier activity have been reported from different parts of the island (Guilizzoni et al.,

12 2006; Humlum et al., 2005; Røthe et al., 2015; Van der Bilt et al., 2015) and sedimentary records from lakes Kongressvatnet and Skardtjørna indicate cooled summers during the time period (D'Andrea et al., 2012; Velle et al., 2011). Further afield, low summer temperatures during this time interval were also reconstructed for northern Scandinavia (Figure 3b; Grudd, 2008). In the marine realm, elevated IRD markers (Figure 3e; Bond et al., 2001), cooler summer sea surface and subsurface temperatures (Risebrobakken et al., 2010; Sarnthein et al., 2003), and increased sea ice (Rasmussen and Thomsen, 2014) in the surrounding areas indicate a cooling of the North Atlantic overlapping with the time interval. Additionally, an intriguing peak 
1 (Figure 3e) of the planktic foraminifer Neogloboquadrina pachyderma ( $\sin$.) $\delta^{18} \mathrm{O}$

2 values is observed in a number of long sediment cores retrieved from different locations

3 in the Barents Sea (core 23258-2: Sarnthein et al., 2003; core JM02-460: Rasmussen et

4 al., 2007; core PSh-5159N: Risebrobakken et al., 2010; core JM09-KA11-GC: Berben

5 et al., 2014), perhaps associated with a cooling of the sea (sub)surface temperatures

6 (Risebrobakken et al., 2010) or increased advection from the cold Barents shelf

7 (Sarnthein et al., 2003) during a time of periodic freshening of the surface and

8 stratification of the upper water column.

9 LIA - the Little Ice Age. A wealth of proxy evidence testifies to the LIA cooling, thought

10 to have been triggered by reduced solar irradiance, extended volcanism and internal

11 characteristics of the ocean-atmosphere system (Miller et al., 2010; 2012; Wanner et al.,

12 2011). The isotopic composition of lake Svartvatnet shows a remarkable depression, with $\delta^{18} \mathrm{O}_{\mathrm{lw}}$ values ca. 8-9\%o below present-day values during the LIA period. There is an initial drop of $2.5 \%$ from present-day levels to $-12 \%$ at ca. $800-700$ cal. yr BP, and a further, more prominent decrease to $-19 \%$ at ca. 350-50 cal. yr BP (ca. 1600-1900 CE). The timing of the event in our record agrees with that in large scale Arctic and Northern

17 Hemisphere temperature compilations by Kaufman et al. (2009) and Marcott et al. (2013), respectively. Abundant proxy evidence on and around Svalbard, consistent with the timing and pattern of the LIA in the Svartvatnet $\delta^{18} \mathrm{O}$ record, testify to the climatic deterioration during the period. The flow of warm Atlantic water was significantly 
1 reduced, Arctic/Polar waters dominated the surface ocean off western Spitsbergen and

2 western Barents Sea (Dylmer et al., 2013) and the western Nordic seas experience their

3 most extensive April sea ice cover since $1200 \mathrm{CE}$ between the $17^{\text {th }}$ and the $19^{\text {th }}$

4 centuries (Macias Fauria et al., 2009). Terrestrial records from Spitsbergen indicate

5 general glacier expansion and decreased air temperatures (Grinsted et al., 2006;

6 Guilizzoni et al., 2006; Isaksson et al., 2003; Kekonen et al., 2005; Lubinski et al.,

7 1999; Røthe et al., 2015; Snyder et al., 2000; Svendsen and Mangerud, 1997; Van Der

8 Bilt et al. 2015; Velle et al., 2011; Werner, 1993), with multiple reports of a two-step

9 progression for the LIA.

10 Factoring in respective age-model uncertainties, it appears that all major negative shifts,

11 i.e. "cold" periods, in the $\delta^{18} \mathrm{O}_{\mathrm{lw}}$ record are roughly synchronous with periods of major

12 negative anomalies in total solar irradiation and high modeled probabilities for extremely cold years in the Nordic Seas (Renssen et al., 2006), and widespread evidence of North Atlantic "cold spells" (Bond et al. 2001; Sarnthein et al. 2003; Solomina et al., 2015; Wanner et al., 2008) linked to solar forcing. However, we emphasize that significant differences exist between the Svartvatnet $\delta^{18} \mathrm{O}_{\mathrm{lw}}$ record and the

17 aforementioned records of solar forcing induced cold events (see e.g. Figure 3e). For example, one of the most prominent of these cold anomalies at ca. $2800 \mathrm{cal}$ yr BP does not appear on the Svartvatnet $\delta^{18} \mathrm{O}_{\mathrm{lw}}$ record. Renssen et al. (2006) simulate $10-15^{\circ} \mathrm{C}$ lower spring (March) air temperatures and 40-60\% enhanced sea ice cover for our study 
1 area during this cold climatic anomaly, absent from our record. This highlights an

2 intriguing non-linearity of the high arctic ocean-atmosphere hydroclimatic system.

3 Additionally we would like to note, that both the 1900-1800 and 3400-3200 cal. yr BP

4 fluctuations are only one-sample events in the record, and thus their apparent match

5 with concurrent climatic trends may be fortuitous. In any case, as single-sample events

6 they should not be considered representative of the actual regional strength, length or

$7 \quad$ structure of the climatic episodes they are tentatively linked to.

$9 \quad$ The cold spells: changed temperatures, moisture sources or seasonality?

10 The northern North Atlantic has a central role in shaping the climate of the study area.

11 There is a strong correlation between mean annual air temperatures measured at the

12 Hornsund Polish Polar Station and temperatures of Atlantic waters from 2000 to 2007

13 (Walczowski, 2013). While their influence on summer air temperatures in the study area

14 is negligible, Atlantic water masses mitigate winter temperature minima through the

15 flux of sensible and latent heat (Walczowski, 2013), and thus winter temperatures play

16 an essential part in variations of mean annual temperatures. Due to the significant

17 effects of sea ice cover on heat exchange with the atmosphere, winter climate of

18 southern Spitsbergen exhibits a substantial sensitivity to seasonal sea ice extent, as

19 demonstrated by high coefficients of determination $\left(r^{2}>0.75\right)$ of winter and spring sea 
1 ice extents in the Greenland and Kara-Barents Seas on Hornsund MATs during 1979-

22009 (Marsz, 2013). Hence, the $\delta^{18} \mathrm{O}_{\mathrm{lw}}$ record can be expected to be strongly influenced

3 by regional winter conditions, particularly by variability in the northward advection of

4 warm Atlantic water masses, extent of sea ice and moisture availability from the

5 adjacent Nordic Seas in addition to general insolation variability. These factors bear

6 great significance to the interpretation of the Svartvatnet $\delta^{18} \mathrm{O}_{\mathrm{lw}}$ record.

7 Yet a significant influence of air temperature on Svartvatnet $\delta^{18} \mathrm{O}_{\mathrm{lw}}$ values is suggested

8 by the similarity of the $\delta^{18} \mathrm{O}$ record to a July air temperature (July-T) reconstruction

9 based on chironomid assemblage analysis from the same sediment core (Figure 3b;

10 Luoto et al., in review). The July-T reconstruction shows a similar general trend, and

11 cold periods are indicated by both records at ca. 3400-3200, 1300-1200 and 350-50 cal.

$12 \mathrm{yr}$ BP. Dissimilarities between the records are expected, because the July-T record is

13 based on 1-cm-thick samples taken every four centimeters throughout the sequence,

14 while the $\delta^{18} \mathrm{O}$ analyses predominantly reflect an average of 2-4 $\mathrm{cm}$ of sediment.

15 Furthermore, based on observations of relative thermal stability of summers compared

16 to the rest of the annual cycle in Spitsbergen for the past decades (Divine et al., 2011;

17 Marsz, 2013) any reconstruction of MAT can be expected to show more variability

18 compared to reconstructed summer temperatures.

19 If assumed to represent solely changes in MAT using $\delta / T$ gradients of 0.65 (Wooller et

20 al., 2004) and 0.71 (Greenland Sea spatial slope; see Materials and Methods, and 
1 Appendix 1), the local minima in $\delta^{18} \mathrm{O}_{\mathrm{lw}}$ values at 3400-3200 and 1250-1100 cal. yr BP

2 translate to MATs $3^{\circ} \mathrm{C}( \pm 3)$ and $6-8^{\circ} \mathrm{C}( \pm 3)$ below the reconstruction mean. For the

3 LIA minimum between 1600 and $1900 \mathrm{CE}$ the $\delta^{18} \mathrm{O}_{\mathrm{lw}}$ record suggests ca. $10-12^{\circ} \mathrm{C}( \pm 6)$

4 lower MATs (Figure 3b). However, it is highly probable that the observed shifts in

$5 \quad \delta^{18} \mathrm{O}_{\mathrm{lw}}$ reflect additional environmental factors and cannot be interpreted as temperature

6 changes alone. This is particularly evident for the drop in $\delta^{18} \mathrm{O}_{\mathrm{lw}}$ values associated with

7 the LIA.

8 The climate of the LIA. In notable contrast to the $10-12^{\circ} \mathrm{C}( \pm 6)$ lower MATs inferred

9 from the $\delta^{18} \mathrm{O}_{\mathrm{lw}}$ record, the summer air temperature reconstruction for lake Svartvatnet

10 (Figure 3b; Luoto et al., in review) indicates only $2^{\circ} \mathrm{C}$ cooler LIA summers than the

11 reconstruction mean, and $3.5^{\circ} \mathrm{C}$ lower than the calculated temperature for the surface sample. However, a more subdued drop in summer air temperature is consistent with the general thermal stability of summer climate in Spitsbergen over the long term (Divine et al., 2011; Marsz, 2013), and considering the strong influence of winter temperatures on the mean annual temperatures discussed above, a transient decoupling of summer and winter temperatures seems to have taken place during the 1600-1900 CE time interval.

17 Indeed, increased seasonality or continentality, i.e. a greater amplitude between winter temperature minima and summer maxima, for the LIA time interval has been inferred based on increases in the amplitude of seasonal $\delta^{18} \mathrm{O}$ variations in ice core records from the Lomonosovfonna glacier in central Spitsbergen (Divine et al., 2011; Grinsted et al., 
1 2006). The $\delta^{18} \mathrm{O}$ based Lomonosovfonna continentality index, mostly driven by winter

2 temperature change, peaks at $1860 \mathrm{CE}$ and declines rapidly thereafter (Grinsted et al.,

3 2006). Increased seasonal temperature variations for the $19^{\text {th }}$ century are known also

4 from Greenland (Box et al., 2009), Iceland, and northern Scandinavia (Hanna et al.,

5 2004; Klingbjer and Moberg, 2003). Considering larger scale trends, a more prominent

6 lowering of winter temperatures agrees also with evidence characterizing the well-

7 known European cold of the LIA during the Maunder Minimum (1650-1700 CE; Eddy,

8 1976) as mainly a spring and winter phenomenon, whereas summers and autumns do

9 not show strong departures from the European $20^{\text {th }}$ century average (Luterbacher et al.,

10 2004; Xoplaki et al., 2005). Thus, an enhanced drop in winter temperatures, leading to a

11 more pronounced lowering of mean annual temperatures compared to summer, is

12 plausible, and we argue that significantly lowered winter temperatures likely account for

13 a part of the outstandingly low LIA $\delta^{18} \mathrm{O}_{\mathrm{lw}}$ values. However, considering that LIA

14 winter temperatures on Svalbard are estimated to have been ca. $4^{\circ} \mathrm{C}$ colder based on ice

15 core records (Divine et al., 2011), a 10-12 ${ }^{\circ} \mathrm{C}$ drop in MAT appears disproportionately

16 large, and requires further examination.

17 In Greenland, a major drop in the GRIP ice core d-excess record at $0.35 \mathrm{ka}$ (ca. 1600

18 CE) indicates changes in moisture source conditions (Hoffmann et al., 2001; Masson-

19 Delmotte et al., 2005), with a reconstructed $1^{\circ} \mathrm{C}$ temperature drop on site in Greenland

20 accompanied by a $2^{\circ} \mathrm{C}$ decrease in moisture source temperature. Similar to Greenland 
1 (Johnsen et al., 1989), Spitsbergen receives much of its precipitation from evaporation

2 taking place in the subtropics (Dickson et al., 2000; Divine et al., 2008; Humlum et al.,

3 2005). However, more proximal sources, most likely the Greenland and Norwegian

4 Seas, seem to have played a significant role in supplying moisture to Spitsbergen

5 (Beaudon et al., 2013; Divine et al., 2008; Hebbeln et al., 1994; Svendsen and

6 Mangerud, 1991). With reference to evidence of much extended sea ice cover around

7 Spitsbergen during the LIA (Grinsted et al., 2006; Macias Fauria et al., 2009; Müller et

8 al., 2012) it is very likely that ice cover -induced changes in the moisture supply from

9 the adjacent seas play a significant part in the prominent drop of $\delta^{18} \mathrm{O}_{\mathrm{lw}}$ values observed

10 at 350-50 cal. yr BP in lake Svartvatnet. A decrease in the proportion of proximally

11 derived, "cold source" moisture, i.e. a shift to greater dominance of more distant,

12 southerly and hence, warmer, moisture sources would result in enhanced Rayleigh

13 distillation of the water vapour leading to more ${ }^{18} \mathrm{O}$ depleted precipitation on site. As

14 inferred for the termination of the LIA in ice core proxies, the rapid recovery from the

15 LIA $\delta^{18} \mathrm{O}_{\text {lw }}$ minimum at ca. 50 cal. yr BP is likely related to fast decline of sea ice in the

16 adjacent Nordic Seas (Divine et al., 2008; Grinsted et al., 2006). For example, the

17 significant shift in the sea-ice cover of the Greenland Sea occurred right after $1880 \mathrm{CE}$,

18 creating year-round open water conditions southwest of Spitsbergen (Divine et al.,

19 2008). The apparent sensitivity of lake Svartvatnet $\delta^{18} \mathrm{O}_{\mathrm{lw}}$ values to variations in sea ice 
1 the dependence of $\delta^{18} \mathrm{O}_{\mathrm{pr}}$ values on sea ice on Spitsbergen (Faber et al., 2016; Macias

2 Fauria et al., 2009), implies that comparable high quality (i.e. lake shielded from

3 glacier/high-altitude melt waters, minimal evaporation, short residence time, stable

4 deposition, sufficient resolution) lacustrine $\delta^{18} \mathrm{O}_{\text {pr }}$ proxy records on Svalbard may be

5 used as indicators of past major fluctuations in sea ice extent.

6 It is additionally possible, that part of the lowering in the $\delta^{18} \mathrm{O}_{\mathrm{lw}}$ value is accounted for

7 by a shift in the seasonal distribution of precipitation towards the cold season, i.e.

8 increased snowfall during the winter months. This would be consistent with scenarios

9 attributing the maximum extent of Svalbard glaciers during the LIA (D'Andrea et al.,

10 2012), and late-Holocene ice advances in general (Müller et al., 2012; Van der Bilt et

11 al., 2015) to cold season precipitation rather than decreased summer temperatures.

12 However, based on the two-year monitoring of precipitation $\delta^{18} \mathrm{O}$ values at the Polish

13 Polar Station indicating winter minimum $\delta^{18} \mathrm{O}_{\mathrm{pr}}$ values of ca. -13 to $-12 \%$, the

14 exceptionally low $\delta^{18} \mathrm{O}_{\mathrm{lw}}$ values observed for the LIA are not attainable even with $100 \%$

15 of precipitation received during the deepest winter. Thus, any seasonality change-

16 induced effects on lake Svartvatnet $\delta^{18} \mathrm{O}_{\mathrm{lw}}$ must be accompanied with an air temperature

17 and/or moisture source related lowering of $\delta^{18} \mathrm{O}_{\mathrm{pr}}$ values.

18 The rest of the record. The issues raised above are naturally pertinent to the

19 interpretation of the negative $\delta^{18} \mathrm{O}_{\mathrm{lw}}$ shifts observed at $3400-3200$ and $1250-1100 \mathrm{cal}$. $\mathrm{yr}$

20 BP. It is particularly clear, that any significant changes in sea ice cover over the 
1 Greenland and Barents Seas will inevitably influence the Svartvatnet $\delta^{18} \mathrm{O}_{\mathrm{lw}}$ record.

2 Unfortunately, much less precise information is available on sea ice conditions in the

3 Nordic Seas over the 5500 year time span represented by our proxy record. The

4 reconstructions available for the eastern Fram Strait region on the northern West

5 Spitsbergen Shelf are not necessarily easily comparable nor mutually consistent.

6 Although some similar trends can be discerned (Cabedo-Sanz and Belt, 2016), sea ice

7 reconstructions based on the biomarker IP25 (Figure 3d; Cabedo-Sanz and Belt, 2016;

8 Müller et al., 2012) and those derived from dinocyst assemblage variations (Bonnet et

9 al., 2010; De Vernal et al., 2013) display clear differences. The biomarker based reconstructions show relatively low general variability, and display minor highs a little before 800 CE (1150 cal. yr BP; Cabedo-Sanz and Belt, 2016) and 1.1 cal. kyr BP

12 (Müller et al., 2012). The dinocyst based reconstructions (Bonnet et al., 2010; De

13 Vernal et al., 2013) show much larger variability, sometimes opposing trends, and do 14 not support a scenario of particularly extended sea ice cover at 3400-3200 and 12501100 cal. yr BP. To the south and south east of Spitsbergen, intermittent seasonal sea ice was inferred from biomarker IP25 indices for the mid to late Holocene in the

17 Kveithola Trough, western Barents Sea, by Berben et al. (2014) and Belt et al. (2015), 18 with somewhat elevated index values roughly between 3.5 and $3 \mathrm{ka} \mathrm{cal}$. yr BP and $1 \mathrm{ka}$ cal. yr BP onwards. For southeastern Barents Sea, peaks at $3.5 \mathrm{ka}$ cal. yr BP and $1.1 \mathrm{ka}$ cal. yr BP in the dinoflagellate cyst based reconstruction (Figure 3d; De Vernal et al., 
1 2013) suggest increased sea ice cover during these periods. In summary, although

2 conclusive evidence of significantly extended sea ice cover for the time periods of

3 interest cannot be drawn from the dinocyst and biomarker based reconstructions, it is

$4 \quad$ very likely that increased sea ice was associated with these periods of general cooling

5 (Bond et al., 2001; Rasmussen and Thomsen 2014; Sarnthein et al., 2003). Thus, the

6 negative shifts in Svartvatnet $\delta^{18} \mathrm{O}_{\text {lw }}$ values probably include a component related to

7 changes in moisture sources, and possibly, in seasonality of precipitation, and do not

8 represent decreased MATs only. Nonetheless, the $\delta^{18} \mathrm{O}_{1 \mathrm{w}}$ record from lake Svartvatnet

9 provides solid evidence of the mid to late Holocene development of meteoric

10 hydroclimate in the European sector of the high Arctic registering perturbations

11 consistent with the timing of well-known historical climate episodes (the RWP, the

12 DACP and the LIA), and clearly demonstrates the inseparable connection between the

13 evolution of North Atlantic conditions and terrestrial climate in the region. Our $\delta^{18} \mathrm{O}_{\mathrm{lw}}$

14 record from Svartvatnet certainly sets the stage for future comparative studies from

15 other lakes in the region.

\section{Conclusion}

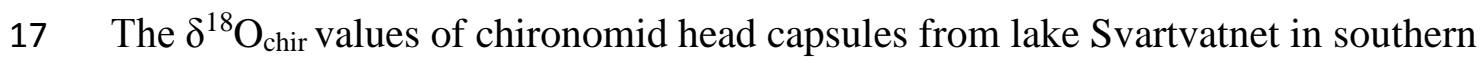

18 Spitsbergen yield a realistic, robust reconstruction of past changes in $\delta^{18} \mathrm{O}_{\mathrm{lw}}$ values over

19 the past 5500 years. Owing to the relatively short residence time and minimal 
1 evaporative influences, and absence of extraneous water inputs from e.g., glacier melt

2 waters, the $\delta^{18} \mathrm{O}_{1 \mathrm{w}}$ values are likely to represent the variations and the absolute level of

$3 \quad \delta^{18} \mathrm{O}$ values of regional precipitation with reasonable precision. The similarity of the

4 trends between the $\delta^{18} \mathrm{O}_{\mathrm{lw}}$ record and a July-T reconstruction based on chironomid

5 assemblages from the same core suggests that temperature plays a significant role in the

6 variations of the $\delta^{18} \mathrm{O}_{\mathrm{lw}}$ record, but the record appears to also be influenced by changes

7 in sea ice extent and possibly, the seasonal distribution of precipitation, limiting our

8 possibilities to present precise estimates of past temperature changes. The strong

9 influence of winter conditions on mean annual temperatures in the study area suggests

10 that the $\delta^{18} \mathrm{O}_{\mathrm{lw}}$ record has particular value in offering insight into the climatic variations

11 of the cool/cold season, in contrast to the majority of terrestrial climate proxies

12 reflecting conditions during the growing season.

13 The Svartvatnet $\delta^{18} \mathrm{O}_{\mathrm{lw}}$ record shows a peak at ca. 1900-1800 cal. yr BP, consistent with

14 the timing of the Roman Warm Period, and negative excursions at 3400-3200, 1250-

151100 and $350-50$ cal. yr BP, increasing in intensity towards the present-day. The time

16 period of the Little Ice Age is manifested in the $\delta^{18} \mathrm{O}_{1 w}$ record as a two-step decrease in

$17 \delta^{18} \mathrm{O}_{\mathrm{lw}}$ values, with a remarkable, 8-9\%o depression in $\delta^{18} \mathrm{O}_{\mathrm{lw}}$ values at 350-50 cal. yr BP.

18 The $\delta^{18} \mathrm{O}_{\mathrm{lw}}$ record suggests that the LIA in southern Spitsbergen was associated with

19 significantly lowered cold season temperatures, i.e. increased seasonal contrasts.

20 Extended sea ice cover, and possibly increased proportion of cold season precipitation, 
1 contributed to the prominent depression in $\delta^{18} \mathrm{O}_{\mathrm{lw}}$ values during the LIA. All the time

2 periods of the negative shifts in the $\delta^{18} \mathrm{O}_{\mathrm{lw}}$ record are linked to widespread evidence of

3 glacier expansion and "cold spells" in the northern North Atlantic testifying to the

4 sensitivity and general potential of high Arctic lacustrine $\delta^{18} \mathrm{O}_{\text {chir }}$ records in tracking

5 terrestrial climate evolution.

\section{Acknowledgements}

7 We express our gratitude to the two anonymous reviewers, whose comments helped

8 improve the manuscript. The input of Paula Niinikoski in CRIS-analyses of the water

9 samples, Juhani Virkanen with water sampling equipment and Alex Pryor in the

10 composite error calculations is gratefully acknowledged. We sincerely thank Lukasz

11 Stachnik, Magdalena Grzesik-Felisiak and Wojciech Mateja for collection of

12 precipitation samples, Mimmi Oksman, Mateusz Damrat and Joanna Pawłowska for

13 help during core collection, and the Polish Polar Station for logistical support.

\section{$14 \quad$ Funding}

15 The project was funded by a grant to A.E.K. Ojala (\#259343) by the Academy of

16 Finland. Tomi P. Luoto received funding from the Emil Aaltonen Foundation (grant

$17 \quad \# 160156)$.

18 References 
1 Aguado E and Burt JE (1999) Precipitation processes. In: Aguado E and Burt JE (eds)

2 Understanding Weather and Climate. Upper Saddle River NJ: Prentice Hall, pp. 46-

3172.

4 Beaudon E, Moore JC, Martma T et al. (2013) Lomonosovfonna and Holtedahlfonna ice

5 cores reveal east-west disparities of the Spitsbergen environment since AD 1700.

6 Journal of Glaciology 59: 1069-1083.

7 Belt ST, Cabedo-Sanz P, Smik L et al. (2015) Identification of paleo Arctic winter sea

8 ice limits and the mariginal ice zone: Optimised biomarker-based reconstructions of late

9 Quaternary Arctic sea ice. Earth and Planetary Science Letters 431: 127-139.

10 Berben SMP, Husum K, Cabedo-Sanz, P et al. (2014) Holocene sub-centennial

11 evolution of Atlantic water inflow and sea ice distribution in the western Barents Sea.

12 Climate of the Past 10: 181-198.

13 Beyerle U, Putschert R, Aeschbach-Hertig W et al. (1998) Climate and groundwater

14 recharge during the last glaciation in an ice-covered region. Science 282: 731-734.

15 Bianchi GG, McCave IN (1999) Holocene periodicity in North Atlantic climate and 16 deep-ocean flow south of Iceland. Nature 397: 515-517. 
1 Birks HH (1991) Holocene vegetational history and climatic change in west

2 Spitsbergen-plant macrofossils from Skardtjørna, an Arctic lake. The Holocene 1: 2093218.

4 Brooks SJ (2006) Fossil midges (Diptera: Chironomidae) as palaeoclimatic indicators

5 for the Eurasian region. Quaternary Science Reviews 25: 1894-1910.

6 Bond G, Kromer B, Beer J et al. (2001) Persistent solar influence on North Atlantic

7 climate during the Holocene. Science 294: 2130-2136.

8 Bonnet S, De Vernal A, Hillaire-Marcel C et al. (2010) Variability of sea-surface

9 temperature and sea-ice cover in the Fram Strait over the last two millennia. Marine

10 Micropaleontology 74: 59-74.

11 Bowen GJ (2016) The Online Isotopes in Precipitation Calculator, version 2.2.

12 http://www.waterisotopes.org.

13 Bowen GJ and Revenaugh J (2003) Interpolating the isotopic composition of modern

14 meteoric precipitation. Water Resources Research 39: 1299.

15 Box JE, Yang L, Bromwich DH et al. (2009) Greenland ice sheet surface air

16 temperature variability: 1840-2007. Journal of Climate 22: 4029-4049.

17 Bronk Ramsey C (2008) Deposition models for chronological records. Quaternary

18 Science Reviews 27: 42-60. 
1 Bronk Ramsey C (2009) Bayesian analysis of radiocarbon dates. Radiocarbon 51: 337-

2360.

3 Brooks SJ and Birks HJB (2004) The dynamics of Chironomidae (Insecta: Diptera)

4 assemblages in response to environmental change during the past 700 years on

5 Svalbard. Journal of Paleolimnology 31: 483-498.

6 Buizert C, Gkinis V, Severinghaus JP et al. (2014) Greenland temperature response to

7 climate forcing during the last deglaciation. Science 345: 1177-1180.

8 Cabedo-Sanz P and Belt ST (2016) Seasonal sea ice variability in eastern Fram Strait 9 over the last 200 years. Arktos 2: 22.

10 Darling WG, Edmunds WM and Smedley PL (1997) The isotopic composition of

11 palaeowaters in the British Isles. Applied Geochemistry 12: 813-829.

12 D'Andrea WJ, Vaillencourt DA, Balascio NL et al. (2012) Mild Little Ice Age and 13 unprecedented recent warmth in an 1800 year lake sediment record from Svalbard.

14 Geology 40: 1007-1010.

15 Dansgaard W (1964) Stable isotopes in precipitation. Tellus 16: 436-468.

16 De Vernal A, Hillaire-Marcel C, Rochon A et al. (2013) Dinocyst based reconstructions 17 of sea ice cover concentration during the Holocene in the Arctic Ocean, the northern

18 North Atlantic Ocean and its adjacent seas. Quaternary Science Reviews 79: 111-121. 
1 Dickson RR, Osborn TJ, Hurrell JW et al. (2000) The Arctic Ocean response to the

2 North Atlantic oscillation. Journal of Climate 13: 2671-2696.

3 Divine D, Isaksson E, Martma T et al. (2011) Thousand years if winter surface air

4 temperature variations in Svalbard and Northern Norway reconstructed from ice-core

5 data. Polar Research 30: 7379.

6 Divine D, Isaksson E, Pohjola V et al. (2008) Deuterium excess record from a small

$7 \quad$ Arctic ice cap. Journal of Geophysical Research 113: D19104.

8 Dylmer CV, Giraudeau J, Eynaud F et al. (2013) Northward advection of Atlantic water 9 in the eastern Nordic Seas over the last 3000 yr. Climate of the Past 9: 1505-1518.

10 Eddy JA (1976) The Maunder minimum. Science 192: 1189-1202.

11 Edwards TDW, Wolfe B and MacDonald GM (1996) Influence of changing

12 atmospheric circulation on precipitation $\delta^{18} \mathrm{O}$-temperature relations in Canada during

13 the Holocene. Quaternary Research 46: 211-218.

14 Faber AK, Vinther BM, Sjolte J et al. (2016) How does sea ice influence $\delta^{18} \mathrm{O}$ of Arctic

15 precipitation? Atmospheric Chemistry and Physics Discussions. DOI:10.5194/acp-2016$16 \quad 100$. 
1 Grinsted A, Moore JC, Pohjola V et al. (2006) Svalbard summer melting, continentality,

2 and sea ice extent from the Lomonosovfonna ice core. Journal of Geophysical Research 3 111: D07110.

4 Grudd H (2008) Torneträsk tree-ring width and density AD 500-2004: a test of climatic

5 sensitivity and a new 1500-year reconstruction of north Fennoscandian summers.

$6 \quad$ Climate Dynamics 31: 843-857.

7 Guilizzoni P, Marchetto A, Lami A et al. (2006) Records of environmental and climatic

8 changes during the late Holocene from Svalbard: paleolimnology of Kongressvatnet.

9 Journal of Paleolimnology 36: 325-351.

10 Hammarlund D (1999) Ostracod stable isotope records from a deglacial isolation

11 sequence in southern Sweden. Boreas 29: 564-574.

12 Hanna E, Jonsson T and Box JE (2004) An analysis of Icelandic climate since the

13 nineteenth century. International Journal of Climatology 24: 1193-1210.

14 Hebbeln D, Dokken T, Andersen ES et al. (1994) Moisture supply for the northern ice

15 sheet growth during the Last Glacial Maximum. Nature 370: 357-360.

16 Heiri O, Schilder J and Van Hardenbroek M (2012) Stable isotopic analysis of fossil

17 chironomids as an approach to environmental reconstruction: state of development and

18 future challenges. Fauna Norvegica 31: 7. 
1 Hoffmann G, Jouzel J and Johnsen SJ (2001) Deuterium excess record from central

2 Greenland over the last millennium: hints of a North Atlantic signal during the little Ice

3 Age. Journal of Geophysical Research 106: 14265-14274.

4 Humlum O, Elberling B, Hormes A et al. (2005) Late-Holocene glacier growth in

5 Svalbard, documented by subglacial relict vegetation and living soil microbes. The

$6 \quad$ Holocene 15: 396-407.

7 Huneau F, Blavoux B, Aeschbach-Hertig W et al. (2002). Paleogroundwaters of the

8 Valréas Miocene aquifer (southeastern France) as archives of the LGM/Holocene

9 transition in the western Mediterranean region. In: Study of Environmental Change

10 Using Isotope Techniques. Proceedings of an International Conference in Vienna,

11 Austria, 23-27 April 2001, C\&S Papers Series No.13, pp.84-90. Vienna: IAEA.

12 IAEA/WMO (2016) Global Network of Isotopes in Precipitation. The GNIP Database.

13 Available at: http://www.iaea.org/water

14 Institute of Geophysics, Polish Academy of Sciences (2016) Meteorological Bulletin,

15 Spitsbergen - Hornsund. Summary of the year 2015. Mandat M, Dąbrowska D,

16 Łaszyca E et al. (eds). Available at: www.glacio-

17 topoclim.org/reports/report_2015_0.pdf, accessed 31.5.2016. 
1 Isaksson E, Divine D, Kohler J et al. (2005). Climate oscillations as recorded in

2 Svalbard ice core $\delta^{18} \mathrm{O}$ records between 1200-1997 AD. Geografiska Annaler Series A $3 \quad 87: 203-214$.

4 Isaksson E, Hermanson M, Hicks S et al. (2003). Ice cores from Svalbard: useful 5 archives of past climate and pollution history. Physics and Chemistry of the Earth 28, $6 \quad 1217-1228$.

7 Johnsen SJ, Clausen HB, Dansgaard, W et al. (1997) The $\delta^{18} \mathrm{O}$ record along the

8 Greenland Ice Core Project deep ice core and the problem of possible Eemian climatic 9 instability. Journal of Geophysical Research 102: 26397-26410.

10 Johnsen S, Dansgaard W and White J (1989) The origin of Arctic precipitation under 11 present and glacial conditions. Tellus Series B 41: 452-468.

12 Jouzel J, Alley RB, Cuffey KM et al. (1997) Validity of the temperature reconstruction 13 from water isotopes in ice cores. Journal of Geophysical Research 102: 26471-26487.

14 Jouzel J, Masson-Delmotte V, Cattani O et al. (2007) Orbital and Millennial Antarctic 15 Climate Variability over the Past 800,000 Years. Science 317: 793-797.

16 Kaufman DS, Schneider DP, McKay NP et al. (2009) Recent warming reverses long17 term Arctic cooling. Science 325: 1236-1239. 
1 Kekonen T, Moore J, Perämäki P et al. (2005) The 800 year long ion record from the

2 Lomonosovfonna (Svalbard) ice core. Journal of Geophysical Research 110: D07304

3 Klein ES, Cherry JE, Young J et al. (2015) Arctic cyclone water vapor isotopes support

4 past sea ice retreat recorded in Greenland ice. Scientific Reports 5: 10295.

5 Klingbjer P and Moberg A (2003) A composite monthly temperature record from

6 Tornedalen in northern Sweden, 1802-2002. International Journal of Climatology 23:

$7 \quad 1465-1494$.

8 Kurki E (2016) The oxygen isotope composition of chironomid chitin as a proxy for

9 oxygen isotope composition of lake water and related climate parameters in southern

10 Spitsbergen, Svalbard, during mid-and late Holocene. Master's thesis, University of

11 Helsinki, Finland.

12 Łącka M, Zajączkowski M, Forwick M et al. (2015) Late Weichselian and Holocene

13 paleoceanography of Storfjordrenna, southern Svalbard. Climate of the Past 11: 587-

$14 \quad 603$

15 Lindner L and Marks L (1993) Middle and Late Quaternary evolution of the Hornsund 16 region, South Spistbergen. Polish Polar Research 14: 275-292. 
1 Ljungqvist FC (2010) A new reconstruction of temperature variability in the extra-

2 tropical Northern Hemisphere during the last two millennia. Geografiska Annaler Series

3 A 92: 339-351.

4 Loosli HH, Aeschbach-Hertig W, Barbecot F et al. (2001) Isotopic methods and their

5 hydrogeochemical context in the investigation of palaeowaters. In: Edmunds WM and

6 Milne CJ (eds) Palaeowaters in coastal Europe: evolution of groundwater since the late

$7 \quad$ Pleistocene. Geological Society, London, Special Publications 189. London: The

8 Geological Society of London, pp. 193-212.

$9 \quad$ Lubinski DJ, Forman SL and Miller GH (1999) Holocene glacier and climate

10 fluctuations on Franz Josef Land, Arctic Russia, $80^{\circ}$ N. Quaternary Science Reviews 18:

$1185-108$.

12 Luoto TP, Ojala A, Brooks S et al. Synchronized proxy-based temperature

13 reconstructions reveal mid-to late Holocene climate oscillations in High Arctic

14 Svalbard. Journal of Quaternary Science, in review.

15 Łupikasza E (2013) Atmospheric precipitation. In: Marsz AA and Styszyńska A (eds)

16 Climate and climate change at Hornsund, Svalbard. Gdynia: The publishing house of

17 Gdynia Maritime University, pp. 199-212.

18 Luterbacher J, Dietrich D, Xoplaki E et al. (2004) European seasonal and annual temperature variability, trends, and extremes since 1500. Science 303, 1499-1503. 
1 McDermott F, Mattey DP and Hawkesworth C (2011) Centennial-scale Holocene

2 climate variability revealed by a high-resolution speleothem $\delta^{18} \mathrm{O}$ record from SW

3 Ireland. Science 294: 1328-1330.

4 Macias Fauria M, Grinsted A, Helama S et al. (2009) Unprecedented low twentieth

5 century winter sea ice extent in the Western Nordic Seas since A.D. 1200. Climate

$6 \quad$ Dynamics 34:781-795.

7 McManus JF, Francois R, Gherardi JM et al. (2004) Collapse and rapid resumption of

8 Atlantic meridional circulation linked to deglacial climate changes. Nature 428: 834-

9837.

10 Marcott SA, Shakun JD, Clark PU et al. (2013) A reconstruction of regional and global

11 temperature for the past 11,300 years. Science 339:1198-1201

12 Majewski W, Szczuciński W and Zajączkowski M (2009) Interactions of Arctic and

13 Atlantic water-masses and associated environmental changes during the last

14 millennium, Hornsund (SW Svalbard). Boreas 38: 529-544.

15 Marsz AA (2013) Air temperature. In: Marsz AA and Styszyńska A (eds) Climate and

16 climate change at Hornsund, Svalbard. Gdynia: The publishing house of Gdynia

17 Maritime University, pp. 145-187. 
1 Masson-Delmotte V, Landais A, Stievenard M et al. (2005) Holocene climatic changes

2 in Greenland: Different deuterium excess signals at Greenland Ice Core Project (GRIP)

3 and NorthGRIP. Journal of Geophysical Research 110: D14102.

4 Miller GH, Brigham-Grette J, Alley RB et al. (2010) Temperature and precipitation

$5 \quad$ history of the Arctic. Quaternary Science Reviews 29, 1679-1715.

6 Miller GH, Geirsdottir A, Zhong Y et al. (2012) Abrupt onset of the Little Ice Age

7 triggered by volcanism and sustained by sea-ice/ocean feedbacks. Geophysical

$8 \quad$ Research Letters 39: L02708.

9 Moros M, Jansen E, Oppo DW et al. (2012) Reconstruction of the late-Holocene

10 changes in the Sub-Arctic Front position at the Reykjanes Ridge, north Atlantic. The

$11 \quad$ Holocene 22: 877-886.

12 Müller J, Werner K, Stein R et al. (2012) Holocene cooling culminates in sea ice

13 oscillations in Fram Strait. Quaternary Science Reviews 47: 1-14.

14 Ojala AEK, Arppe L, Luoto TP et al. (2016) Sedimentary environment,

15 lithostratigraphy and dating of sediment sequences from Arctic lakes Revvatnet and

16 Svartvatnet in Hornsund, Svalbard. Polish Polar Research 37: 23-48. 
1 Perner K, Jennings AE, Moros M et al. (2016) Interaction between warm Atlantic-

2 sourced waters and the East Greenland Current in northern Denmark Strait $\left(68^{\circ} \mathrm{N}\right)$

3 during the last 10600 cal BP. Journal of Quaternary Science 31: 472-483.

4 Perner K, Moros M, Lloyd JM et al. (2015) Mid to late Holocene strengthening of the

5 East Greenland Current linked to warm subsurface Atlantic water. Quaternary Science

$6 \quad$ Reviews 129: 296-307.

7 Pohjola V, Moore JC, Pohjola V et al. (2002) Effect of periodic melting on geochemical

8 and isotopic signals in an ice core on Lomonosovfonna, Svalbard. Journal of

$9 \quad$ Geophysical Research 107: 4036.

10 Pryor AJ, Stevens RE, O'Connell TC et al. (2014) Quantification and propagation of 11 errors when converting vertebrate biomineral oxygen isotope data to temperature for 12 palaeoclimate reconstruction. Palaeogeography, Palaeoclimatology, Palaeoecology 13 412: 99-107

14 Rasmussen TL and Thomsen E (2009) Stable isotope signals from brines in the Barents

15 Sea: implications for brine formation during the last glaciation. Geology 37: 903-906.

16 Rasmussen TL and Thomsen E (2014) Brine formation in relation to climate changes

17 and ice retreat during the last 15,000 years in Storfjorden, Svalbard, $76-78^{\circ} \mathrm{N}$.

18 Paleoceanography 29: 911-929. 
1 Rasmussen TL, Thomsen E, Ślubowska MA et al. (2007) Paleoceanographic evolution

2 of the SW Svalbard margin $\left(76^{\circ} \mathrm{N}\right)$ since 20,000 14C yr BP. Quaternary Research 67:

$3 \quad 100-114$.

4 Rasmussen TL, Forwick M and Mackesen A (2012) Reconstruction of inflow of

5 Atlantic Water to Isfjorden, Svalbard during the Holocene: Correlation to climate and

6 seasonality. Marine Micropaleontology 94-95: 80-90.

7 Remenda VH, Cherry JA and Edwards TWD (1994) Isotopic composition of old ground

$8 \quad$ water from Lake Agassiz: implications for late Pleistocene climate. Science 266: 1975-

91978.

10 Renssen H, Goosse H and Muscheler R (2006) Coupled climate model simulation of

11 Holocene cooling events: oceanic feedback amplifies solar forcing. Climate of the Past

$12 \quad 2: 79-90$.

13 Reusche M, Winsor K, Carlson AE et al. (2014) ${ }^{10}$ Be surface exposure ages on the late-

14 Pleistocene and Holocene history of Linnébreen on Svalbard. Quaternary Science

15 Reviews 89: 5-12.

16 Risebrobakken B, Jansen E, Andersson C et al. (2003) A high-resolution study of

17 Holocene paleoclimatic and paleoceanographic changes in the Nordic Seas.

18 Paleoceanography 18: 1017. 
1 Risebrobakken B, Moros M, Ivanova E et al. (2010) Climate and oceanographic

2 variability in the SW Barents Sea during the Holocene. The Holocene 20: 609-621.

3 Rotschky G, Schuler TV, Haarpaintner J et al. (2011) Spatio-temporal variability of

4 snowmelt across Svalbard during the period 2000-08 derived from

5 QuikSCAT/SeaWinds scatterometry. Polar Research 30: 5963.

6 Rozanski K, Araguás-Araguás L and Gonfiantini R (1992) Relation between long-term

7 trends of oxygen-18 isotope composition of precipitation and climate. Science 258: 981-

8985.

9 Rozanski K, Araguas-Araguas L and Gonfiantini R (1993) Isotopic patterns in modern

10 global precipitation. In: Swart PK, Lohmann KC, McKenzie J et al. (eds) Climate

11 change in continental isotopic records. Washington: American Geophysical Union, pp.

$12 \quad 1-36$

13 Røthe TO, Bakke J, Vasskog, K et al. (2015) Arctic Holocene glacier fluctuations

14 reconstructed from lake sediments at Mitrahalvøya, Spitsbergen. Quaternary Science

15 Reviews 109: 111-125.

16 Sarnthein M, Van Kreveld S, Erlenkeuser H et al. (2003). Centennial-to-millennial scale

17 periodicities of Holocene cimate and sediment injections off the western Barents shelf, $18 \quad 75^{\circ}$ N. Boreas 32: 447-461. 
1 Sauer PE, Miller GH and Overpeck JT (2001) Oxygen isotope ratios of organic matter

2 in arctic lakes as a paleoclimate proxy: field and laboratory investigations. Journal of

3 Paleolimnology 25: 43-64.

4 Snowball I, Zillén L, Ojala A et al. (2007) Fennostack and Fennorpis: varve dated

5 Holocene palaeomagnetic secular variation and relative palaeointensity stacks for

6 Fennoscandia. Earth and Planetary Science Letters 255: 106-116.

7 Snyder JA, Werner A and Miller GH (2000) Holocene cirque glacier activity in western

8 Spitsbergen, Svalbard: sediment records from proglacial Linnévatnet. The Holocene 10:

$9 \quad 555-563$.

10 Solomina ON, Bradley RS, Hodgson DA et al. (2015) Holocene glacier fluctuations.

11 Quaternary Science Reviews 111: 9-34.

12 Steffensen JP, Andersen KK, Bigler M et al. (2008) High-resolution Greenland ice core

13 data show abrupt climate change happens in few years. Science 321: 680-684.

14 Steinhilber F, Beer J and Fröhlich C (2009) Total solar irradiance during the Holocene.

15 Geophysical Research Letters 36: L19704.

16 Svendsen JI and Mangerud J (1991) Paleoclimatic inferences from glacial fluctuations

17 on Svalbard during the last 20000 years. Climate Dynamics 6: 213-220. 
1 Svendsen JI and Mangerud J (1997) Holocene glacial and climatic variations on

2 Spitsbergen, Svalbard. The Holocene 7: 45-57.

3 Vachon RW, Welker JM, White JWC et al. (2010) Moisture source temperatures and

4 precipitation $\delta^{18} \mathrm{O}$-temperature relationships across the United States. Water Resources

$5 \quad$ Research 46: W07523.

6 Van der Bilt WGM, Bakke J, Vasskog K et al. (2015) Reconstruction of glacier

7 variability from lake sediments reveals dynamic Holocene climate in Svalbard.

$8 \quad$ Quaternary Science Reviews 126: 201-218.

$9 \quad$ Velle G, Kongshavn K and Birks HJB (2011) Minimizing the edge-effect in

10 environmental reconstructions by trimming the calibration set: Chrinomid-inferred

11 temperatures from Spitsbergen. The Holocene 21: 417-430.

12 Verbruggen F, Heiri O, Reichart GJ et al. (2010a) Chironomid $\delta^{18} \mathrm{O}$ as a proxy for past

13 lake water $\delta^{18} \mathrm{O}$ : a Lateglacial record from Rotsee (Switzerland). Quaternary Science

14 Reviews 29: 2271-2279.

15 Verbruggen F, Heiri O, Reichart GJ et al. (2010b) Effects of chemical pretreatments on

$16 \delta 180$ measurements, chemical composition, and morphology of chironomid head

17 capsules. Journal of Paleolimnology 43: 857-872. 
1 Verbruggen F, Heiri O, Reichart GJ et al. (2011) Stable oxygen isotopes in chironomid

2 and cladoceran remains as indicators for lake-water $\delta^{18} \mathrm{O}$. Limnology and Oceanography

$3 \quad 56: 2071-2079$.

4 Vinther BM, Clausen HB, Fisher DA et al. (2008) Synchronizing ice cores from the

5 Renland and Agassiz ice caps to the Greenland Ice Core chronology. Journal of

$6 \quad$ Geophysical Research 113: D08115.

7 Walczowski W (2013) Atlantic Water in the Nordic Seas. Properties, Variability,

$8 \quad$ Climatic Importance. New York: Springer.

9 Wang Y, Francis DR, O’Brien DM et al. (2008) A protocol for preparing subfossil

10 chironomid head capsules (Diptera: Chironomidae) for stable isotope analysis in

11 paleoclimate reconstruction and onsiderations of contamination sources. Journal of

12 Paleolimnology 40: 771-781.

13 Wang YV, O'Brien DM, Jenson J et al. (2009) The influence of diet and water on the

14 stable oxygen and hydrogen isotope composition of Chironomidae (Diptera) with

15 paleoecological implications. Oecologia 160: 225-233.

16 Wanner H, Beer J, Buetikofer J et al. (2008) Mid- to Late Holocene climate change: an

17 overview. Quaternary Science Reviews 27: 1791-1828. 
1 Wanner H, Solomina O, Grosjean M et al. (2011). Structure and origin of Holocene

2 cold events. Quaternary Science Reviews 30: 3109-3123.

3 Werner A (1993) Holocene moraine chronology, Spitsbergen, Svalbard: lichenometric

4 evidence for multiple Neoglacial advances in the Arctic. The Holocene 3: 128-137

5 Werner K, Spielhagen RF, Bauch D et al. (2013) Atlantic water advection versus sea-ice

6 advances in the eastern Fram Strait during the last 9 ka: multiproxy evidence for a two-

7 phase Holocene. Paleoceanography 28: 283-295.

8 Werner K, Frank M, Teschner C et al. (2014) Neoglacial change in deep water

9 exchange and increase in sea-ice transport through eastern Fram Strait: evidence from

10 radiogenic isotopes. Quaternary Science Reviews 92: 190-207.

11 Wolfe BB, Edwards TWD, Elgood RJ et al. (2001) Carbon and oxygen isotope analysis

12 of lake sediment cellulose: methods and applications. In: Last WM and Smol JP (eds)

13 Physical and Geochemical Methods. Tracking Environmental Change Using Lake

14 Sediments vol. 2. Dordrecht: Kluwer Academic Publishers, pp. 373-400.

15 Wooller MJ, Francis D, Fogel ML et al. (2004) Quantitative paleotemperature estimates

16 from $\delta^{18} \mathrm{O}$ of chironomid head capsules preserved in arctic lake sediments. Journal of

17 Paleolimnology 31: 267-274. 
1 Wooller MJ, Pohlman JW, Gaglioti BV et al. (2012) Reconstruction of past methane

2 availability in an Arctic Alaska wetland indicates climate influenced methane release

3 during the past $\sim 12,000$ years. Journal of Paleolimnology 48: 27-42.

$4 \quad$ Wooller M, Wang Y and Axford Y (2008) A multiple stable isotope record of Late

5 Quaternary limnological changes and chironomid paleoecology from northeastern

$6 \quad$ Iceland. Journal of Paleolimnology 40: 63-77.

7 Xoplaki E, Luterbacher J, Paeth H et al. (2005) European spring and autumn

8 temperature variability and change of extremes over the last half millennium.

9 Geophysical Research Letters 32: L15713.

10 Ziaja W (2004) Spitsbergen landscape under $20^{\text {th }}$ century climate change: Sorkapp

11 Land . AMBIO: A Journal of Human Environment 33: 295-299.

12 Zuber A, Weise SM, Motyka J et al. (2004) Age and flow pattern of groundwater in a

13 Jurassic limestone aquifer and related Tertiary sands derived from combined isotope,

14 noble gas and chemical data. Journal of Hydrology 286: 87-112.

\section{Appendix: $\delta^{18} O$ data and reconstructed MAT changes}

The oxygen isotope composition of chironomid chitin $\left(\delta^{18} \mathrm{O}_{\text {chir }}\right)$ and lake Svartvatnet water $\left(\delta^{18} \mathrm{O}_{\mathrm{lw}}\right)$, and the interpreted changes in mean annual temperature (MAT-index) along the sediment sequence. $\delta^{18} \mathrm{O}_{\mathrm{lw}}$ was reconstructed using the calibration of Verbruggen et al. (2011). MAT-index 1 shows temperature changes relative to the reconstruction mean applying Wooller et al. (2004). Correspondingly, MAT-index 2 was calculated from reconstructed $\delta^{18} \mathrm{O}_{\mathrm{lw}}$ values based on the spatial correlation between $\delta^{18} \mathrm{O}_{\mathrm{ppt}}$ and 
MAT at IAEA monitoring stations adjacent to the Greenland Sea (see sheet "Slope data" below). Precision refers to IRMS measurement precision estimate determined by replicate analyses of similar biogenic materials of different sample mass, with larger measurement precision estimates for samples with smaller masses. The composite error represents the total error associated with the reconstructed $\delta^{18} \mathrm{O}_{\mathrm{lw}}$ value or index to the left including measurement and calibration errors (c.f. Pryor et al. 2014). See main text for explanations on calculations of MAT-indeces.

\begin{tabular}{|c|c|c|c|c|c|c|c|c|}
\hline $\begin{array}{l}\text { depth } \\
\text { (cm) }\end{array}$ & $\begin{array}{l}\delta^{18} O_{\text {chir }} \\
(\% o)\end{array}$ & $\begin{array}{l}\text { precision } \\
(\% \circ)\end{array}$ & $\begin{array}{l}\delta^{18} O_{l w} \\
(\% \circ)\end{array}$ & $\begin{array}{l}\text { composite } \\
\text { error (\%o) }\end{array}$ & $\begin{array}{l}\text { MAT-index } \\
1\left({ }^{\circ} \mathrm{C}\right)\end{array}$ & $\begin{array}{l}\text { composite } \\
\text { error }\left({ }^{\circ} \mathrm{C}\right)\end{array}$ & $\begin{array}{l}\text { MAT-index } 2 \\
\left({ }^{\circ} \mathrm{C}\right)\end{array}$ & $\begin{array}{l}\text { composite } \\
\text { error }\left({ }^{\circ} \mathrm{C}\right)\end{array}$ \\
\hline $0-2$ & 14.1 & 1.5 & -9.2 & 2.4 & 1.5 & 3.0 & 1.8 & 3.6 \\
\hline $2-3$ & 13.3 & 0.4 & -10.3 & 1.4 & 0.3 & 1.9 & 0.3 & 2.5 \\
\hline $4-5$ & 13.0 & 0.4 & -10.6 & 1.5 & -0.1 & 2.0 & -0.2 & 2.5 \\
\hline $6-7$ & 7.7 & 0.4 & -17.6 & 1.6 & -8.2 & 2.3 & -9.9 & 2.9 \\
\hline $8-12$ & 6.9 & 2.5 & -18.7 & 3.6 & -9.5 & 4.5 & -11.5 & 5.5 \\
\hline $12-16$ & 11.5 & 1.5 & -12.6 & 2.4 & -2.4 & 3.0 & -2.9 & 3.7 \\
\hline $16-20$ & 11.9 & 0.4 & -12.1 & 1.5 & -1.8 & 2.0 & -2.2 & 2.5 \\
\hline $20-24$ & 11.9 & 0.4 & -12.1 & 1.5 & -1.8 & 2.0 & -2.2 & 2.5 \\
\hline $24-28$ & 13.8 & 0.4 & -9.6 & 1.4 & 1.1 & 1.9 & 1.4 & 2.5 \\
\hline $28-30$ & 13.2 & 0.4 & -10.4 & 1.4 & 0.1 & 1.9 & 0.1 & 2.5 \\
\hline $30-31$ & 9.1 & 0.4 & -15.7 & 1.5 & -6.1 & 2.1 & -7.3 & 2.7 \\
\hline $32-35$ & 13.9 & 0.4 & -9.5 & 1.4 & 1.2 & 1.9 & 1.4 & 2.5 \\
\hline $34-35$ & 9.0 & 0.4 & -16.0 & 1.5 & -6.3 & 2.2 & -7.6 & 2.7 \\
\hline $36-40$ & 14.0 & 1.5 & -9.4 & 2.4 & 1.4 & 3.0 & 1.7 & 3.6 \\
\hline $40-43$ & 14.1 & 0.4 & -9.2 & 1.4 & 1.6 & 1.9 & 1.9 & 2.5 \\
\hline $44-47$ & 14.5 & 0.4 & -8.7 & 1.4 & 2.1 & 1.9 & 2.5 & 2.5 \\
\hline $48-51$ & 12.5 & 0.4 & -11.2 & 1.5 & -0.8 & 2.0 & -1.0 & 2.5 \\
\hline $52-53$ & 16.3 & 0.4 & -6.3 & 1.4 & 5.0 & 1.9 & 6.0 & 2.6 \\
\hline $56-58$ & 13.3 & 0.4 & -10.2 & 1.4 & 0.4 & 1.9 & 0.5 & 2.5 \\
\hline $60-62$ & 13.4 & 0.4 & -10.1 & 1.4 & 0.5 & 1.9 & 0.6 & 2.5 \\
\hline 64-67 & 14.8 & 0.4 & -8.3 & 1.4 & 2.6 & 1.9 & 3.1 & 2.5 \\
\hline $68-72$ & 14.3 & 0.4 & -9.0 & 1.4 & 1.8 & 1.9 & 2.2 & 2.5 \\
\hline $72-75$ & 13.3 & 0.4 & -10.2 & 1.4 & 0.4 & 1.9 & 0.5 & 2.5 \\
\hline $76-80$ & 13.3 & 0.4 & -10.2 & 1.4 & 0.4 & 1.9 & 0.4 & 2.5 \\
\hline $80-84$ & 13.6 & 0.4 & -9.9 & 1.4 & 0.7 & 1.9 & 0.9 & 2.5 \\
\hline
\end{tabular}




\begin{tabular}{|l|r|r|r|r|r|r|r|r|}
\hline $84-87$ & 13.6 & 0.4 & -9.9 & 1.4 & 0.8 & 1.9 & 0.9 & 2.5 \\
\hline $88-92$ & 11.4 & 0.4 & -12.8 & 1.5 & -2.6 & 2.0 & -3.2 & 2.6 \\
\hline $92-96$ & 13.8 & 0.4 & -9.6 & 1.4 & 1.1 & 1.9 & 1.3 & 2.5 \\
\hline $96-99$ & 13.9 & 0.4 & -9.5 & 1.4 & 1.2 & 1.9 & 1.5 & 2.5 \\
\hline $100-103$ & 12.8 & 0.4 & -10.9 & 1.5 & -0.4 & 2.0 & -0.5 & 2.5 \\
\hline $104-107$ & 13.3 & 0.4 & -10.2 & 1.4 & 0.4 & 1.9 & 0.4 & 2.5 \\
\hline $108-111$ & 12.5 & 0.4 & -11.3 & 1.5 & -1.0 & 2.0 & -1.1 & 2.5 \\
\hline $112-116$ & 13.9 & 0.4 & -9.4 & 1.4 & 1.3 & 1.9 & 1.6 & 2.5 \\
\hline $116-119$ & 13.7 & 0.4 & -9.7 & 1.4 & 0.9 & 1.9 & 1.1 & 2.5 \\
\hline $120-123$ & 13.4 & 0.4 & -10.2 & 1.4 & 0.4 & 1.9 & 0.5 & 2.5 \\
\hline $124-127$ & 14.1 & 0.4 & -9.3 & 1.4 & 1.5 & 1.9 & 1.8 & 2.5 \\
\hline $128-131$ & 14.3 & 0.4 & -9.0 & 1.4 & 1.8 & 1.9 & 2.2 & 2.5 \\
\hline $132-136$ & 13.8 & 0.4 & -9.5 & 1.4 & 1.2 & 1.9 & 1.4 & 2.5 \\
\hline $136-140$ & 14.3 & 0.4 & -9.0 & 1.4 & 1.8 & 1.9 & 2.2 & 2.5 \\
\hline $140-143$ & 14.6 & 0.4 & -8.6 & 1.4 & 2.3 & 1.9 & 2.7 & 2.5 \\
\hline $144-148$ & 14.5 & 0.4 & -8.7 & 1.4 & 2.1 & 1.9 & 2.5 & 2.5 \\
\hline $148-150$ & 13.2 & 0.4 & -10.4 & 1.4 & 0.1 & 1.9 & 0.1 & 2.5 \\
\hline $152-154$ & 14.2 & 0.4 & -9.0 & 1.4 & 1.7 & 1.9 & 2.1 & 2.5 \\
\hline $156-159$ & 14.0 & 0.4 & -9.4 & 1.4 & 1.4 & 1.9 & 1.6 & 2.5 \\
\hline $160-163$ & 13.2 & 0.4 & -10.3 & 1.4 & 0.2 & 1.9 & 0.3 & 2.5 \\
\hline
\end{tabular}

\section{References:}

Pryor, A.J., Stevens, R.E., O'Connell, T.C. and Lister, J.R. 2014. Quantification and propagation of errors when converting vertebrate biomineral oxygen isotope data to temperature for palaeoclimate reconstruction. Palaeogeography, Palaeoclimatology, Palaeoecology 412, 99-107.

Wooller, M.J., Francis, D., Fogel, M.L., Miller, G.H., Walker, I.R. and Wolfe, A.P. 2004. Quantitative paleotemperature estimates from $\delta 180$ of chironomid head capsules preserved in arctic lake sediments. Journal of Paleolimnology 31, 267-274

Verbruggen, F., Heiri, O., Reichart, G.J., Blaga, C. and Lotter, A.F. 2011. Stable oxygen isotopes in chironomid and cladoceran remains as indicators for lake-water $\delta 180$. Limnology and Oceanography 56, 2071-2079. 


\section{Appendix:}

mean annual $\delta 180 p r$ and MAT at stations adjacent to the "Greenland Sea sector"

\section{Station}

Prins Christians Sund, Greenland

Nord, Greenland

Danmarkshavn, Greenland

Scoresby Sund, Greenland

Groennedal, Greenland

Reykjavik, Iceland

Ny Ålesund, Spitsbergen

Isfjord, Spitsbergen

Hornsund, Spitsbergen

\section{Long-term}

MAT

$\begin{array}{rrrl}0.9 & -11.7 & 1 \text { excluded } \\ -17.6 & -25.0 & 12 & \\ -10.5 & -17.8 & 24 & \\ -7.8 & -13.9 & 5 & \\ 1.2 & -11.2 & 14 & \\ 4.9 & -8.3 & 41 & \\ -4.6 & -11.7 & 24 & \\ -5.0 & -9.6 & 7 & \\ -2.1 & -7.3 & 2 \text { excluded }\end{array}$

Except for the Hornsund Polish Polar Station, all data from IAEA/WMO (2016).

IAEA/WMO, 2016. Global Network of Isotopes in Precipitation. The GNIP Database.

Accessible at: http://www.iaea.org/water

\begin{tabular}{lr}
\hline Regression statistics & \\
\hline Multiple R & 0.908828 \\
R square & 0.825968 \\
Adjusted R Square & 0.791162 \\
Standard Error & 2.644804 \\
Observations & 7 \\
\hline
\end{tabular}

\begin{tabular}{lrccccc}
\hline & & Standard & & Lower & Upper \\
& Coefficients & Error & t-stat & $p$-value & $95 \%$ & $95 \%$ \\
\hline Intercept & -9.94184 & 1.292088 & -7.69439 & 0.000591 & -13.2633 & -6.62042 \\
x-variable & 0.707979 & 0.145334 & 4.871381 & 0.004587 & 0.334385 & 1.081573 \\
\hline
\end{tabular}

